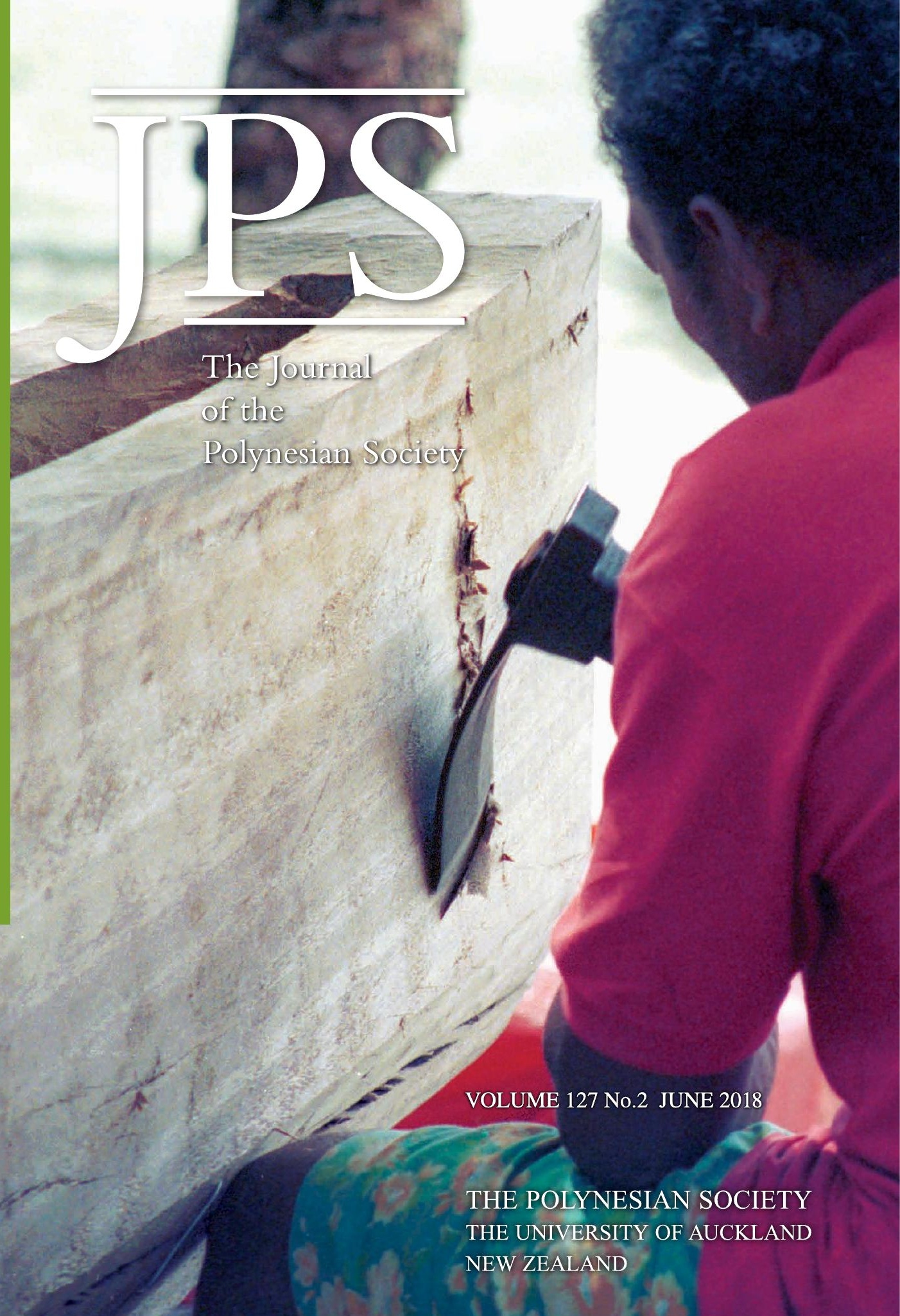




\title{
PERFORMING CULTURAL HERITAGE WITH TIFAIFAI, TAHITIAN “QUILTS”
}

\author{
JOYCE D. HAMMOND \\ Western Washington University
}

People of the Society Islands, as well as of other islands in what is today French Polynesia, began creating piecework and appliqué textiles from imported Western cloth sometime in the early to mid-19th century. Tifaifai, an indigenous word widely used for the textiles, have been continuously created ever since. ${ }^{1}$ Research into tïfaifai (de Chazeaux and Frémy 2012; Grand 2012; Hammond 1986a, 1986b, 2014, 2015; O'Reilly 1959) and other textile traditions of Eastern Polynesia, most notably Hawaiian quilts called kapa apana (Akana 1981; Arthur 2010a, 2010b; Brandon and Woodard 2003; Hammond 1986a; Serrao et al. 2007) and Cook Islands tivaevae (Hammond 1986a; Herda 2002, 2011; Küchler and Eimke 2009; Rongotea 2001), ${ }^{2}$ reveals both similarities and differences between tïfaifai and those traditions. ${ }^{3}$ The diversity and special character of the traditions are embedded within unique histories.

In this article, I focus on contemporary appliqué tīfaifai of French Polynesia, arguing that their increasingly important role in conveying islanders' pride in Polynesian culture and identity is manifested in the ways that tîfaifai publicly perform le patrimoine or faufa 'a tupuna (French and indigenous language terms, respectively, for heritage). ${ }^{4}$ Drawing upon new materialist theory, performance studies and visual display concepts, I discuss ways in which tîfaifai help to transmit and modify culture across time and space, shape social relationships and influence people's constructions of Mā'ohi (indigenous people of French Polynesia) cultural identities. Insights from the performative turn in anthropology and folklore studies, many of which address identity expression (Bauman 1989; Conquergood 1989; Fine and Speer 1992; Smith 2011; Turner 1986), fit well with the ideas of new materialism theory (Gell 1998; Latour 2005; Miller 2005; Schouwenburg 2015; Storey 2017) that foregrounds the agency of things. Asserting that performance theory opens up all forms of expressive culture, including textile arts, to performance inquiry, Conquergood has written, "A performance perspective emphasizes the experiential, processual, creative, actor-oriented constructions of culture" (1992: 211). ${ }^{5}$

A central tenet of new materialism theory is that as actants (anything that can modify other actors, whether people or things), things are co-constitutive with people who may interact with them in myriad ways (Barad 2007; Dant 
1999; Miller 1987; Schweitzer and Zerdy 2014). Dant asserts that objects "extend human action and mediate meanings between humans", and clarifies that "objects are shaped by a culture which defines what certain types of things can $d o$ " (1999: 13; italics in original). Things are part of networks of relations and, thus, co-shape social worlds. Embedded in the larger social and cultural relationships with the people who create them, display them, see them, photograph them, buy them, bestow them upon others and otherwise engage with them, tiffaifai are, to borrow Schouwenburg's words, "produced and productive, generated and generative" (2015: 65). Since tïfaifai meanings are not fixed in any given moment, tïfaifai, like other objects, are "constructed and interpreted according to particular contexts and circumstances" (Kerlogue 2004: viii). This means that they are embedded in many social and cultural relationships both within French Polynesia and beyond as they persist in constant negotiation with other actants (including people). As part of a continuous and vibrant tradition that spans more than 150 years, tïfaifai are constantly generating and being generated by the circumstances associated with a wide range of societal changes. This leads individual tîfaifai, like other things, to have individual cultural biographies (Appadurai 1986; Kopytoff 1986; Martinson 2014), and for all tîfaifai, as a culturally recognised category of things, to have a collective cultural biography that reveals their interactions with various shifting contextual circumstances in society over time.

The ever-changing and developing biographical history of tîfaifai is one which has had a co-constitutive impact on me in my many years of thinking and writing about tĩfaifai themselves and the people who make them. Beginning in the 1970s when I first embarked on research into tïfaifai, I began a relationship that has recently deepened as a result of returning to French Polynesia to learn of changes over the intervening decades. My first encounter with tîfaifai in the mid-1970s was through the only scholarly article that had been written about the subject (O'Reilly 1959). In 1978, when I embarked on a year of fieldwork to learn about tïfaifai and other regional forms of Polynesian "quilts", ${ }^{6}$ I was not surprised, after reading O'Reilly's work, to find that most tîfaifai were locked away in chests and armoires in people's homes, removed to be draped over a guest's bed or displayed on furniture, beds and walls in homes for holidays when the presence of many visitors turned people's homes into a more public setting. Tïfaifai were typically not for daily use. The cost of materials and the large amount of time necessary for completing a hand-sewn tîfaifai were significant aspects of their value. Tiffaifai were not created for the maker(s) themselves. They were given as special gifts, especially for family members' rites of passage such as birthdays and weddings (some families also used them to wrap the 
deceased). Sometimes people incorporated tīfaifai into temporary structures for gatherings associated with a rite of passage. They were also bestowed upon esteemed people in recognition of their contributions and services or given to others on special occasions such as a departure. In these situations, people often wrapped tïfaifai around one or more of the recipient(s).There were some church bazaars where tîfaifai were sold in either a completed state or, as in the case of some appliqué-style tîfaifai, in a basted, less expensive form. The purchaser could then finish sewing the tîfaifai before giving it as a gift. I saw an exposition of tîfaifai in Pape'ete, Tahiti, during the 1970s when I was in French Polynesia, and then, as now, some tiffaifai that were on display could be purchased.

The proliferation of tīfaifai in public venues that I encountered when I returned to French Polynesia for short periods of time in 2010 and 2014, and six months respectively in 2013 and 2017, initially astonished me since many who discussed tîfaifai with me in 1977-78 predicted that the textiles' creation seemed doomed. This opinion was based on an increasing number of younger women seeking employment outside the home who also expressed a disinterest in spending time making tîfaifai. When I first returned after thirty years, much had changed. Rather than having to seek out individuals at home to discuss their views about tïfaifai and asking to see a household's tiffaifai, I was able to connect with the organisation Te Api Nui O Te Tifaifai (The Renewal of Tĩfaifai), created in 1997-98 with the sole mission of "promoting, preserving and protecting" tiffaifai. The Service de l'Artisanat Traditionnel de Polynésie française (Government Office for Traditional Arts and Crafts of French Polynesia), founded in 1984, was another important source of information and connection. Through these two organisations, I met and interviewed women who had travelled abroad with their tiffaifai to international expositions. In 2011 I travelled to California to meet with members of Te Api Nui O Te Tifaifai who attended the International Pacific Festival of Quilts and displayed some of their tïfaifai at the de Young Museum of San Francisco. I attended Te Api Nui O Te Tifaifai's two-week salons of tîfaifai held in Pape'ete, Tahiti, in 2013 and 2014. During the salons, I had conversations with many of the artisans and their visitors. I attended a number of events in which tiffaifai were displayed, and I saw photos of tïfaifai in local media of newspapers, magazines and television. Most revelatory of changes in tïfaifai creation and use was the frequency with which tîfaifai were displayed in public places. It quickly became apparent that tïfaifai were playing key performative roles in communicating ideas of cultural heritage that encompassed not only the cultural legacy of tïfaifai themselves but also, more broadly, ideas about cultural legacy and heritage as a whole. 
While former traditions remain strong, such as bestowing tïfaifai on family members for rites of passage and decorating the home for special occasions (with some households displaying tïfaifai in homes on a more frequent basis), the role that tiffaifai play in the present has greatly expanded past practices of using tîfaifai in public arenas. Over the past 40 years, the textiles have increasingly figured in the changing circumstances of islanders, and today they often perform in public venues as visible expressions of Mā'ohi cultural heritage and identity. In political and cultural events, contests to commemorate public anniversaries, and expositions both in French Polynesia and abroad, tîfaifai are prominently and proudly displayed. Some are permanently hung in public buildings; others are displayed for varying lengths of time in temporary or permanent structures in the islands. Some tīfaifai are transported abroad by their creators to be shown in international textile exhibitions. Some are gifted or sold to international museums and other institutions that place them in gallery settings. In public demonstrations of tïfaifai creation and in public ceremonies of giving tïfaifai to notable people through the ritual of wrapping the honoured person, tiffaifai extend and expand upon past practices that have long been associated with the textiles. The new and enlarged performative modes of display are augmented by the proliferation of public images of tïfaifai through print and digital media. The contemporary performative role of tīfaifai, to employ Clifford's use of the term "indigenous articulation", demonstrates the various ways in which material culture can be combined with local needs, events and practices. As Clifford states, "[t]raditions articulate, selectively remember and connect pasts and presents" (2001: 475). Contemporary public tïfaifai displays and uses simultaneously reference past understandings associated with tiffaifai, even as they transform the social environment through innovative and strategic performances that shape contemporary meanings about tiffaifai, Mā'ohi cultural heritage and islander identities. Social, economic and political influences have all impacted indigenous French Polynesians' ideas of cultural heritage, and these are creatively articulated in the performative, public roles of tïfaifai in French Polynesia.

This article is divided into two interrelated parts. In the first, I describe and discuss various public contexts in which contemporary tīfaifai perform heritage. Using the display of objects in museums as an example, Kerlogue notes that the role of displayed things can be seen as "analogous to that of an actor [and] their time in an exhibition as a stage performance" (2004: viii). As actants themselves in interaction with tïfaifai, people who make, display, give, receive or otherwise interact with tīfaifai in public events and places are themselves engaged in performative acts. The decisions and acts of those who are involved in the displays of tîfaifai are, to borrow from Kerlogue's 
performative analysis (2004: 3 ), engaged in the cultural constructs of social practices. In some contexts, the creators of tiffaifai are expected to explain the intended messages they intend tiffaifai to convey. The co-constitutive acts of tîfaifai creating artisan identities and artisans creating tīfaifai meanings are easily detected in these circumstances. Artisans' public performances of creating tîfaifai in some venues constitute another way in which tîfaifai and people are co-constitutive of one another. However, other performances are equally rich and may involve a wide range of people's motivations, emotions and actions. For example, tïfaifai may impact people by eliciting feelings of pride, sparking memories, inducing nostalgia, inspiring creativity, fuelling imaginaries of the past and present, or any combination of these and other outcomes.

In the second part of the article, I present highlights from the biography of tifaifai that illustrate the co-constitutive nature of societal, economic and political changes within the textile tradition of tîfaifai. By contextualising the "life story" of tiffaifai within the actions of people, government policies, economic circumstances and other impactful phenomena, I hope to present a background to reasons that cultural heritage is being extensively performed with tīfaifai in French Polynesia today.

\section{PUBLIC PERFORMANCES}

\section{Expositions and Contests}

The most numerous venues for tîfaifai performance of islanders' cultural heritage are expositions and contests, often with the two performance forms combined. Every year since its founding, the organisation Te Api Nui O Te Tifaifai has mounted a combined exhibition and competition called Salon du Tĩfaifai. The two-week event takes place in rooms within governmental buildings, usually in the mairie 'city hall' of French Polynesia's capital, Pape'ete, Tahiti. Anyone from French Polynesia who belongs to an artisan organisation and submits a hand-sewn tïfaifai that conforms to a given year's theme may participate and compete for a cash prize. The themed tîfaifai are fully displayed as hangings, and prizes are awarded at the end of the salon period (Fig. 1). While the main activity of the salon is for participants to sell completed or basted tiffaifai, the display of the themed tiffaifai is the most important performative aspect of the event. Attendees to the salon view the themed tiffaifai, and people may see images of the salon on television and in newspapers. As Varutti (2015: 1042) notes, visual display and performance constitute one of the four important strategies and discourses for artisans to engage in the act of "crafting heritage", and she asserts that making material culture visible in display is "a recurrent strategy deployed by artisans to communicate value and authenticity". 


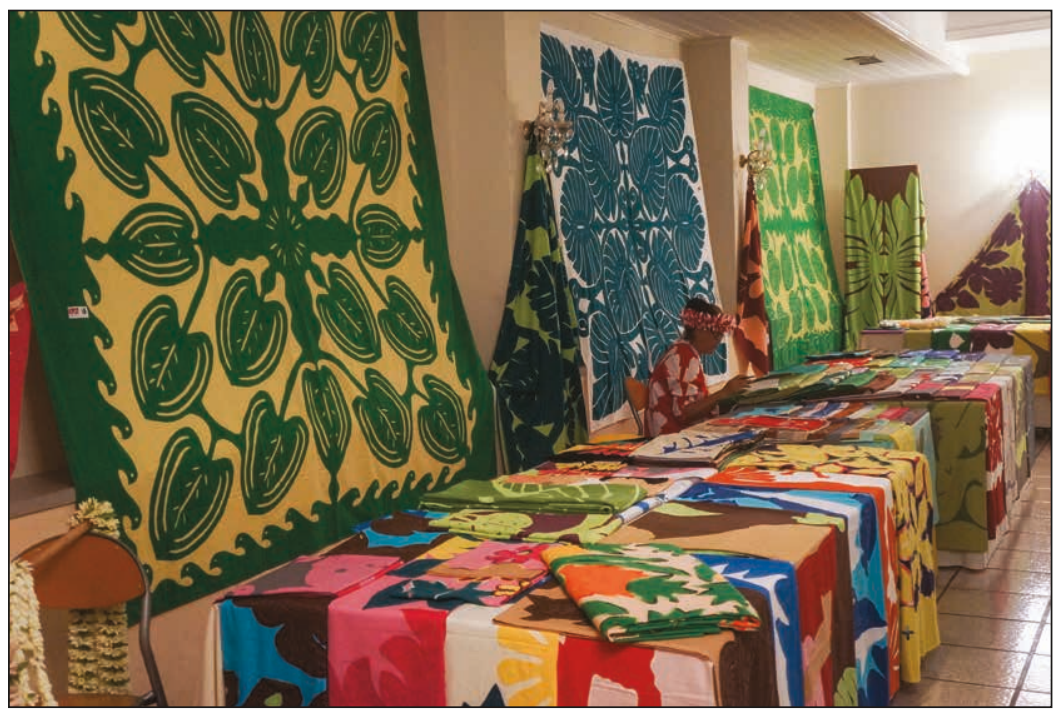

Figure 1. Some of the thematic tîfaifai with 'ape designs hang on a wall in the Pape'ete town hall during the 2013 Salon du Tífaifai. Assorted finished and basted tîfaifai of different sizes and with various designs and colours are displayed on the tables. Photograph by the author.

Another annual setting for the performance of tiffaifai is that of the Heiva Rima' $\overline{1}$, an artisans' event held in July. During the two-week fair, artisans show and sell handwork made from materials regarded as traditionalshells, pearls, pandanus, coconut, wood and cloth. ${ }^{7}$ Competitions centre on creatively addressing an annual theme which typically celebrates the island environment, the traditional way of life, islanders' skills and knowledge or some combination of these subjects. Many plants long associated with utilitarian and aesthetic purposes have inspired themes that celebrate environmental resources and islanders' extensive knowledge of ways to use them. Past themes have included "Medicinal Trees", "Fruits from Under the Ground" (i.e., tubers) and "The Season of Abundance". Other themes have been "Birds and Flowers" and "Fishing". Participants sometimes hang a tîfaifai that features thematic content as a decorative element of their booth.

The tîfaifai contest of the Heiva Rima'i consists of a small team or a pair of people who are presented with fabric to fashion an appliqué tīfaifai to the basted stage. Tables are provided for the artisans to use as they design 
the upper layer of the tiffaifai, either using a pattern they have brought or drawing freehand on the fabric. The design layer is cut out, placed on the background fabric, pinned and finally basted. At the end of the allotted time over a two-day period, the competitors' work is judged by a group of older women knowledgeable about tîfaifai. They assess each team's creation in terms of the criteria of an appropriate design for the theme and the tifaifai's artistic merits. One of the artisans of each team provides an explanation for the choice of elements within the design. For example, at the 2013 Heiva Rima' 1 contest with the theme "The Many Values of the Coconut Tree", Elvina Beauvilain explained the tiffaifai that she and her partner created. It featured two coconut trees and other elements such as sprouting coconuts, coconut frond baskets and a house with a coconut-leaf roof. Expounding on the many uses of the coconut tree may be regarded as a "private performance" for the jury members only, but the actual construction of a tiffaifai to its basted stage is a performance that anyone attending the Heiva Rima' $\overline{1}$ can view.

Other such performances of fashioning tīfaifai are often associated with contests, as, for example, a competition held in Pape 'ete in 2010 to celebrate the capital's 120th anniversary. Organisers called for tiffaifai designs that would honour the city's name (which translates to 'Water Basket') and reference a story, legend or historical event associated with Pape'ete's springs, pools or rivers in its design. The winning entry depicted the pool where Queen Aimata Pōmare IV bathed. The queen's face and hair appeared in the centre, and the pool was surrounded by birds, leaves, ferns and flowers known to have existed during her lifetime (1813-1877).

Whether a contest allows for artisans to create a tîfaifai before the contest is convened (as for the tīfaifai salons of Te Api Nui O Te Tifaifai) or includes the actual process of completing steps in its creation as spectators watch, the contest tiffaifai are always hung for a specified period of time so that they may be viewed and admired. Performing as actants, the displayed tîfaifai communicate the vitality of the tiffaifai tradition, themes associated with Polynesian values, the ongoing significance of tïfaifai as Polynesian art and the public role of tïfaifai as heritage objects. Their display, and the display of those making the tiffaifai, if that is part of a competition, may encourage people to make tîfaifai themselves.

\section{Designs and Motifs}

Since tīfaifai have been created for over 150 years, any tïfaifai is part of the tîfaifai tradition and may project a message of the persistence of the tradition for those who know something of the history of tïfaifai. A single tîfaifai, then, can perform a role of referencing all tiffaifai. The choice of motifs for specific tïfaifai is also a means of relaying messages about cultural heritage, 
the history of changes to the tîfaifai tradition, and specific practices and things associated with Mā'ohi cultural heritage. I turn now to a consideration of motifs on appliqué tïfaifai, since much of the performative role of tïfaifai is centred in makers' choices of motifs and other design elements.

Several years after its founding, Te Api Nui O Te Tifaifai adopted a practice that has strengthened tiffaifai messages about cultural patrimony on two fronts. Every other year, the organisation's designated theme for the contest-entry tīfaifai is one of the older, "classic" tîfaifai designs, regarded as traditional, that were prevalent in earlier decades. This is done, as the organisation's president Béatrice Legayic explained to me, in order to protect and encourage the ongoing creation of former tiffaifai designs (pers. comm., 14 March 2013). In 2011, the theme "Tifaifai d'antan" (Tiffaifai of Yore) could be addressed by salon participants by using the motifs of royal crowns (symbols of the Tahitian Pōmare Dynasty), handheld fans such as those island women make and use at church services, or hanging oil lamps of the kind seen in early Christian churches in the islands. The designated 2013 salon theme was a reproduction of older tîfaifai with an 'ape design; 'ape plants are part of a group of plants that have been used for various purposes. The theme for 2015 was the design "Te Moemoeā nō Iotefa" (Joseph's Dream), a biblical design incorporating symbols of the famous dream: stars, moons and sheaves of wheat. In an interview for an article entitled "Tifaifai, Treasure of Polynesian Heritage", in Hiro 'a, Journal d'informations culturelles (2015), Legayic stated: "It is a biblical theme which reminds us that the tifaifai, in the past, were used in a precise way, for important events. During religious celebrations, they were, for example, in a prominent place in the church". In 2017 the theme for a classic design was a head garland (hei) made of maire, a kind of fern that grows in many valleys. Maire hei are still worn for festive occasions.

As these stipulated motifs demonstrate, by using older designs, contemporary tîfaifai can perform what tiffaifai makers of the past thought worthy of depicting. The textiles simultaneously pay homage to older tïfaifai and to those who made and used them. Such contemporary tïfaifai embody ideas, values and references that are reinvoked by being recreated and represented. For example, the tiare Tahiti 'Tahitian flower' design incorporates the fragrant white flower that is indigenous to the Society Islands and considered French Polynesia's "national" flower. ${ }^{8}$ Older tïfaifai designs with this flower often included motifs of both buds and open flowers arranged to resemble the circular hei 'neck or head garland' made from the flowers and worn by islanders in the past, as well as today, for a variety of occasions. The connotations associated with the flower, transferred to the design on a tîfaifai, also include wearing an individual tiare Tahiti behind the left or right ear to denote a wearer's romantic relationship status and the use of the flowers to scent coconut oil, used on the body and hair. 
Older tïfaifai designs are created by folding the top, appliqué layer of material into fourths and then cutting the design to reveal a rotational, fourpart symmetrical design that is sewn to the backing fabric. The different colours chosen for the top design layer and the backing layer are typically contrastive (such as red on white, white on green, or red on yellow). However, some tîfaifai creators take advantage of the increased colour choices now available and may even use two shades of the same colour. Te Api Nui O Te Tifaifai does not require that creators use vintage fabric or sew lengths of cloth together to achieve the correct size for the top and bottom layers of the textile, as was once necessary. In other words, although older designs are featured every other year in the Salon as a way to honour their creation in the past and preserve their memory, current practices demonstrate that even "old-style" tîfaifai can be modified within the continuous tradition of tîfaifai-making as a whole.

Other contemporary tīfaifai, including the themed tïfaifai of Te Api Nui $\mathrm{O}$ Te Tifaifai's contests on alternate years to the traditional designs, often draw upon the pictorial aspects of what are called tableau tîfaifai (Hammond 2015). This style typically displays a scene made from different pieces of cloth of various colours appliquéd to a background cloth. The pieces are shaped to resemble what they depict, and colour choices are often made with realism in mind. Unlike the rotational, four-part symmetrical designs of older-style textiles, tableau tïfaifai motifs may be asymmetrical and usually have a top-to-bottom orientation to "read" the design.

From their prominent emergence in the 1980s, when artisan leaders challenged tîfaifai makers to create new work by requiring conformity to a theme or encouraged creators to devise new subject matter, tableau (or création) tīfaifai have facilitated more narrative work. These kinds of appliqué tîfaifai contrast with those with older designs, a majority of which depicted only one kind of flower or plant. It should be noted, however, that some precedents existed for the storytelling function of many contemporary tîfaifai in some of the older-style appliqué designs. Examples include "Joseph's Dream", performing a message of islanders' embrace of Christianity as well as the biblical story; the tiare 'apetahi flower design, linked with a legend of two lovers who were separated; and the tiare Tahiti flower with its many associations with islanders' celebrations.

What is especially noteworthy about many of the newer motifs of tableaustyle applique tîfaifai is that they express ideas about islanders' cultural heritage. Many scenes depict the close relationship of Polynesians to their environment and its resources, those elements that are increasingly being recognised worldwide as societies' environmental or natural patrimony. For example, some early themes of the Te Api Nui O Te Tifaifai salons that inspired the creation of tableau tîfaifai included "The Riches of the Sea", 
"The Valleys" and "The Birds of My Island" (Fig. 2). Other tableau tïfaifai, whether created for the salon or not, show former or ongoing distinctively Polynesian activities and objects associated with cultural heritage. Tableau tīfaifai frequently display iconic cultural items such as outrigger canoes and houses constructed from natural materials, as well as cultural activities such as fishing, making music and fashioning flower garlands. A distinctive tīfaifai created by the renowned artisan Aline Amaru performs as a reflexive statement about the significance of tïfaifai and tïfaifai creators. The tableaustyle tïfaifai depicts Amaru herself sewing a tïfaifai. In another tïfaifai by Amaru, royalty of the Tahitian Pōmare Dynasty (1788-1880) are depicted (Fig. 3). This tiffaifai, now owned by the Queensland Art Gallery, was declared "un patrimoine" (a legacy object) by one of the staff of the Government Office of Traditional Arts and Crafts during a conversation I had with personnel about tīfaifai and cultural heritage (pers. comm., 19 April 2013).

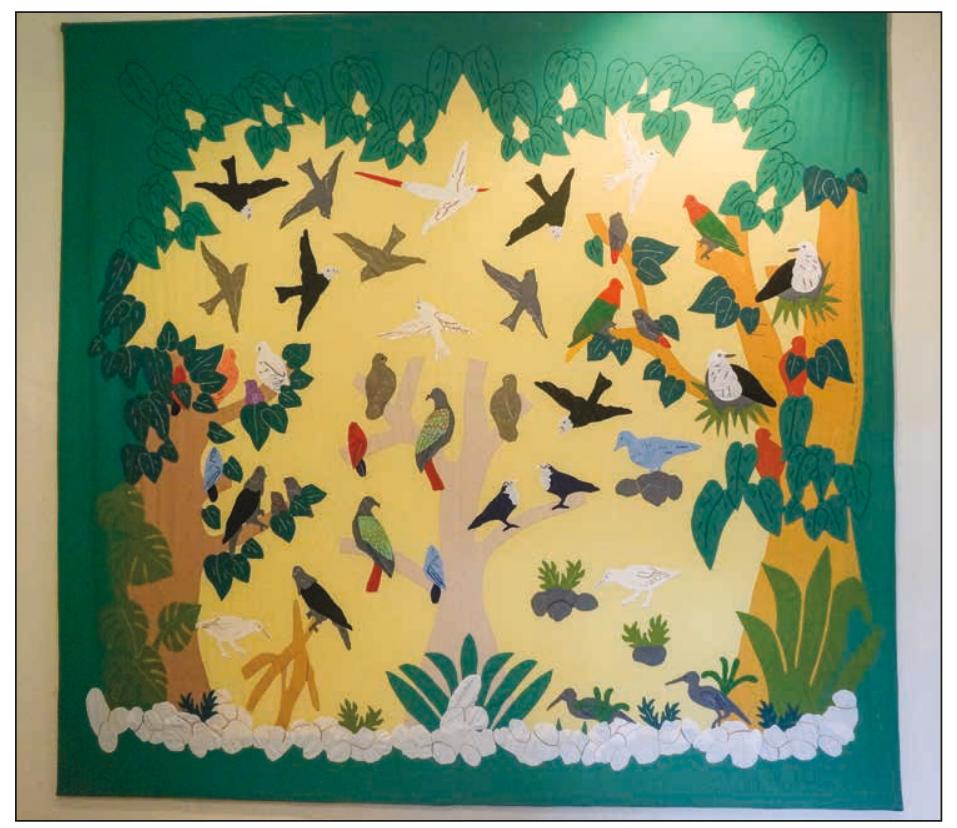

Figure 2. A tîfaifai created by Virginie Biret with birds of Tahiti hangs in the reception area of the Pape'ete residence provided to French High Commissioners when they serve in French Polynesia. Photograph by the author, 2013. 
In 2014 the Salon du Tîfaifai featured competition tīfaifai based on whatever participants wished to create. Many of the tïfaifai were identifiably linked with cultural heritage understandings, but even some that on first viewing might have seemed to have little to do with cultural heritage were linked with the past. For example, Elsa Tahi explained her tïfaifai with three horses by referring to ways horses figured in islanders' past lives as forms of transportation and entertainment through horse races (pers. comm., 29 April 2014).

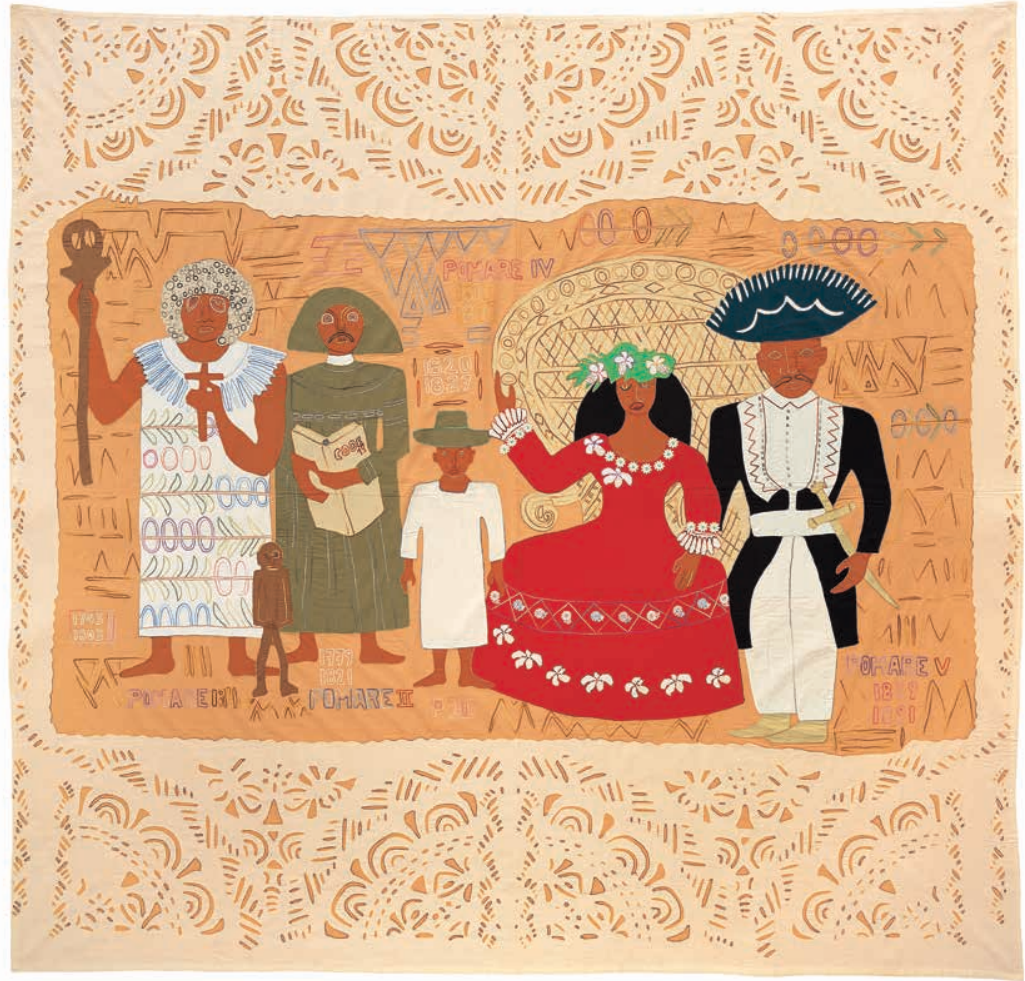

Figure 3. A Tĩfaifai by Aline Amaru, La Famille Pomare (Pa'oti style) 1991, Queensland Art Gallery Collection. This tableau-style tîfaifai depicts the rulers of the Pōmare Dynasty and was inspired by a woodcut by Jean- François Favre. Symmetrical nana 'o cut-out designs are worked into the top layer of fabric and serve as a frame for the central area that display the royal figures, their titles and years of their lives. Photograph courtesy of QAGOMA. 
Benjamin Rangivaru, one of the few men who has exhibited his work in the Salon, designed a tîfaifai that his mother hand-sewed. It portrayed Te Ariki Munanui, the legendary king or chief of Hao in the Tuamotu Islands, the island of origin for Rangivaru and members of his family. On various days during the Salon, renditions of the legend of the chief were recounted to me, to the jury and to a television crew reporting on the Salon. Rangivaru named the different figures in the design for me and told me of their relationships to Te Ariki Munanui. He also explained why he depicted the giant chief as kneeling, an action which raised dust and sent birds flying upwards, as depicted on the tiffaifai. When a local television crew filmed Rangivaru's tïfaifai, Riakina Teikipupuni, his mother, broke into a song about the chief in her indigenous language of the Tuamotu Islands. ${ }^{9}$ On another occasion, two of Rangivaru's relatives came to see the tiffaifai and brought a guitar with them. They, Rangivaru and his mother sang two songs about the chief that detailed his exploits. Later, Rangivaru told me that the first song was about the hero becoming a king and the second was a song of a battle that the hero and his warriors waged (pers. comm., 30 April 2014). In these instances, the performance of the tîfaifai sparked human performances of songs related to the tîfaifai's subject matter.

Emilienne Wohler's tīfaifai of four environmental elements - fire, air, water and earth - took first prize in the 2014 Salon. Since Wohler embroidered the names of the elements in French and depicted the elements themselves as female Polynesian figures, she combined Western and Polynesian influences shaping islanders' lives. The four figures, one in each quadrant, dominate the tïfaifai, thereby emphasising and celebrating Polynesian mythological figures and legends. In her account of the different aspects of her tïfaifai, she explained connections among the elements as a cycle. In my fieldnotes of 26 April 2014, I described her account:

\footnotetext{
She pointed out that each female figure was holding something. Air is Vahine Tāhirihiri ('Fan Woman', legendary on the island of Tahiti) and she holds a fan. The wind fans the flames of the fire. The fire figure holds aloft a flame and water puts out the fire. Water, represented by the mermaid-like creature (mokorea or meherio), is holding a pearl. Water allows the earth (shown as a tree holding a sprouting coconut) to give life. She said the cycle can also be understood in terms of a life cycle. She spoke of the little rocks at the end of the hair filaments of the fire figure as a kind of lava called Pele's tears (Pele is the volcano goddess associated with the Hawaiian Islands).
}

Not all recent innovations in tïfaifai designs and motifs are tied to a tableau style of tïfaifai. In 1997, the Tamarii artisan couple from the Marquesas Islands introduced a new appliqué design based on Marquesan carving designs (Hammond 2014: 60). Drawing upon her husband's carving designs executed 
in wood and stone, Emma Tamarii "translated" them into cloth. From the beginning, some tïfaifai nana 'o 'sculpted tïfaifai' have been made by folding the design layer of cloth in fourths, in the manner of traditional appliqué designs. Other nana 'o designs are juxtaposed with pictorial tableau elements as seen in Amaru's Pōmare family tīfaifai (Fig. 3). The cross-reference of one expressive medium to another artistic form underlined the celebration of many Mā'ohi visual forms of expressive culture as part of cultural heritage in the latter part of the 21 st century. Tifaifai nana 'o quickly gained popularity with other tîfaifai artisans and probably provided some of the impetus for more motifs in tableau tïfaifai of carved sculptures, wooden bowls and drums - objects historically associated with male artisans.

\section{Display Sites: Special Events and Permanent Placements}

An illustration of the innovative ways that tîfaifai may be used to invoke the past and foreground cultural heritage occurred in Pape'ete in April 2017, when Hine, a Tahiti-based magazine for women, hosted an evening themed "Belle Époque" to coincide with the Festival Hōho'a Nui, an exhibition of photography in large format. In addition to a style show of clothing reminiscent of island dresses worn during the 1940s to the 1970s, a photo scene was arranged for female guests to pose in the vintage-replica dresses they were encouraged to wear. There they could be photographed seated in an ornate, carved love seat and later receive a mock cover of the magazine featuring their image. A beautiful traditional appliqué tīfaifai with a floral design was hung on the wall behind the loveseat to complete the emulated historical scene. For many locals, this arrangement could call to mind a well-known 1930s photograph of Queen Marau, wife of Pōmare V, last ruling monarch of Tahiti, seated before a tîfaifai hung behind her chair (see Hammond 2014: 47). Then, as now, a displayed tïfaifai behind a person could convey an identity linked to island culture and the prestige of owning such a valuable and treasured object. However, the Hine "photo studio" with a borrowed tîfaifai for the posers emphasised the nostalgic imaginary of a past period in the islands' history.

Another example of the performative role of tiffaifai in a specific context that clearly referenced cultural legacy in general and tīfaifai specifically may be cited in a 2013 contest centred on schoolchildren's performance of 'orero, traditional oratory in indigenous Reo Mā'ohi (the language previously refereed to as Tahitian). Two tîfaifai were hung at the back of a stage where the children, dressed in costumes as Mā'ohi forbearers, delivered memorised short speeches as part of educational programming intended to revitalise or introduce indigenous language learning to island youth. The stage itself was decorated with items associated with Polynesian culture such as pandanus hats, shell necklaces, wooden sculptures and drums. Given their size and placement, two tïfaifai hung at the back of the stage were prominent features 


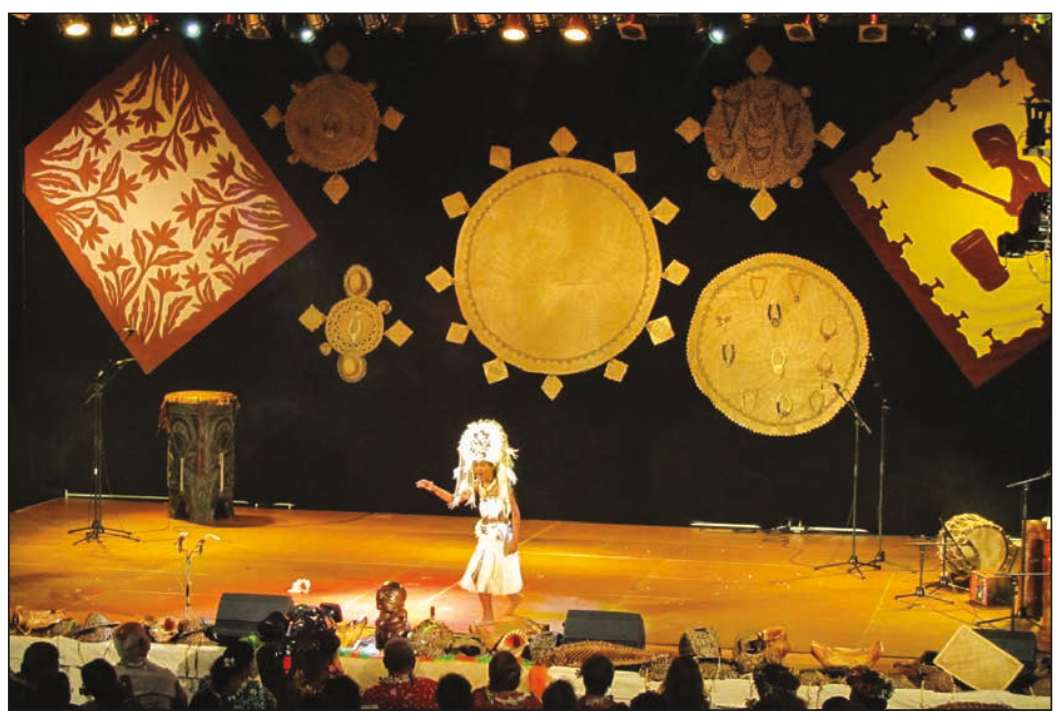

Figure 4. Tïfaifai decorate the back of a stage at an 'orero 'oratory' competition for youth held in Paea, Tahiti, in 2013. Photograph courtesy of Caroline Valentin.

of the performances (Fig. 4). Juxtaposed with other Polynesian objects, the tìfaifai were part of the cultural legacy the whole event celebrated. In addition, the designs on the tîfaifai evoked the traditional in two ways. One tîfaifai was made in the "classic" style of an appliquéd floral design. The other, of the newer tableau style, presented a grouping of motifs representing such traditional artefacts as a warrior's spear, a $t i$ ' $i$ 'humanoid carving', a $t u$ ' $i$ or penu 'stone beater for making the food called poi', a drum and a canoe paddle. The prominent display of both tîfaifai (which could perhaps be further interpreted as a nod to both female and male participants in the programme since flowers are especially associated with femininity and the objects of the other tîfaifai with masculinity) were part of the message of tradition being passed to the younger generation.

Since women have always been the main creators of tiffaifai, ${ }^{10}$ the textiles can communicate much about their makers' identities as women, as well as societal expectations and developments that involve women in Tahitian society (see Hammond 1986b). Tïfaifai are sometimes used as a backdrop for beauty contests or hung in a setting where beauty contest competitors are 
photographed. Colourful and associated with the womanly arts of beautifying the home and creating gifts for kin that emphasise familial ties, the tiffaifai serve as symbols of long-established feminine roles in the culture. The presence of the textiles simultaneously reinforces the identity of the candidates as young women connected to and proud of their culture.

The many miniature appliqué tîfaifai that are framed and hung along the corridors of the maternity ward of Tahiti's very modern hospital may be interpreted as signalling cultural heritage and the role of women as mothers (Figs 5a and 5b). As one woman explained to me, for her, the small, decorative textiles called to mind the once more common practice of a woman creating a tïfaifai for her unborn child during her nine-month pregnancy (pers. comm., 14 March 2017). Placed within the modern maternity ward, the miniature tīfaifai may also transmit a message about cultural heritage and cultural continuity: despite changes in society, cultural identity and knowledge of
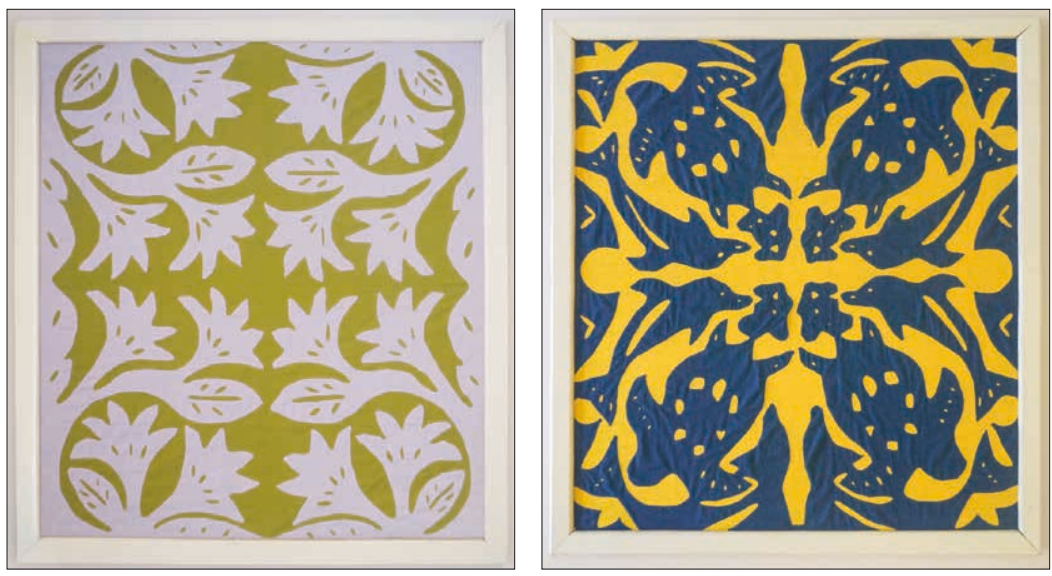

Figures $5 \mathrm{a}$ and $5 \mathrm{~b}$. The two miniature tîfaifai pictured here (measuring $58 \mathrm{~cm} \times$ $68 \mathrm{~cm}$ in their frames) are among more than 25 miniature tifaifai of different designs and colours that hang in the halls of the maternity ward of the Ta'one Hospital in Pirae, Tahiti. The tîfaifai on the left presents the tiare 'apetahi design which, for many islanders, evokes a well-known legend of two lovers from the island of Ra'iātea, the only place where the flower grows. The tifaifai on the right features turtles and dolphins. Marine animals, associated with Mā'ohi culture and environment, have been incorporated into tîfaifai designs much more frequently in recent decades than in the past. Photograph by the author, 2017. 
cultural values are essential for future generations.

Performance of cultural heritage is enacted through other tîfaifai hung in public or semi-public places, as, for example, the beautiful floral-design tîfaifai displayed behind the main desk of the library of the University of the South Pacific (Fig. 6). In that location, the tiffaifai can play the actant role of signalling messages about the artistic achievements of Polynesians, their creativity, their love of natural beauty and their pride in their culture. Given the many associations of tifaifai with the past, particularly in their roles as gifts to family members and objects of great value to bestow on others, the prominently displayed tïfaifai is capable of evoking many nostalgic and identification-with-place emotions. Situated where all will see it, the tīfaifai may even be said to "brand" the institution as Polynesian.

A broad message of Polynesian cultural heritage is also established in other contexts where tīfaifai are displayed. More specific and nuanced understandings depend on context and associations that viewers may bring

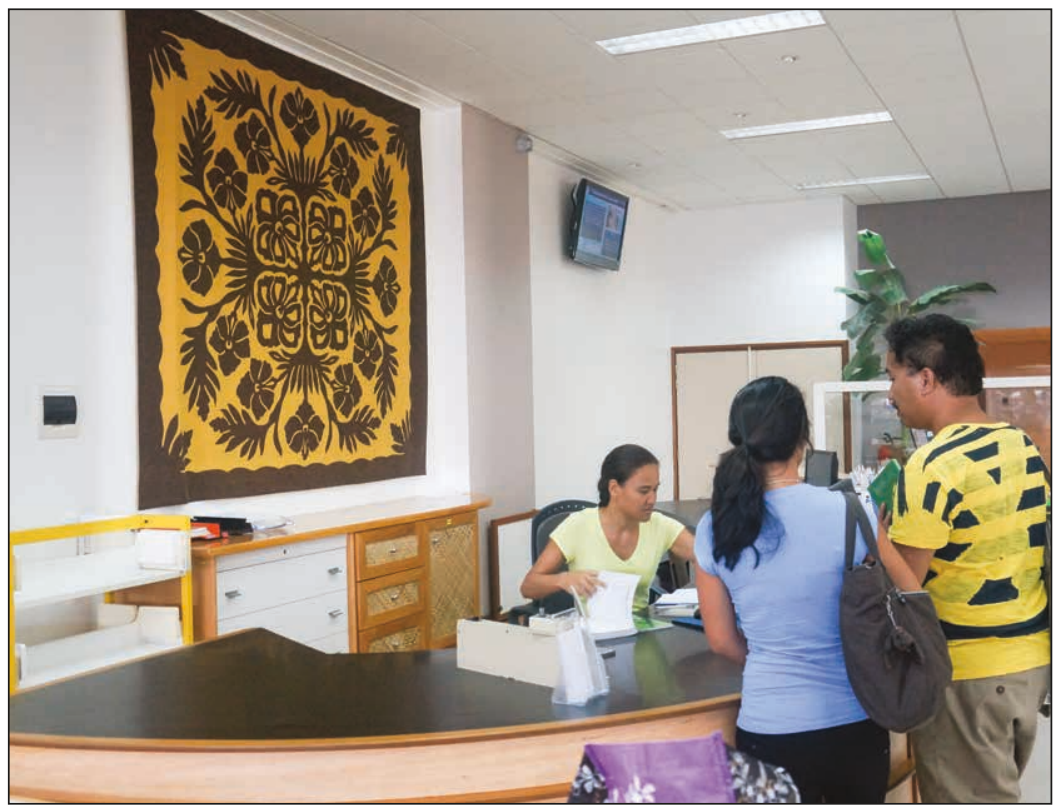

Figure 6. A tiffaifai with a hibiscus ('aute) design is hung in the library of the University of the South Pacific, Tahiti. Photograph by the author, 2013. 
to the presence of displayed tïfaifai. For example, several tîfaifai grace the walls of reception areas in the Pape'ete home established for all the French High Commissioners who reside in the capital of French Polynesia during their tenure (see Fig. 2). Visitors to the French High Commissioner's home may be reminded of the cultural legacy of tiffaifai, the birds who live in the islands (depicted on a tableau-style tîfaifai) and the generosity of Mā'ohi to non-islanders (labels that appear next to the tîfaifai explain their gift status).

In the annual March celebrations of the 1797 arrival of missionaries from the London Missionary Society, members of the Mā'ohi Protestant Church in Pape'ete display tïfaifai in an arena where speeches, songs and dances are performed. Press coverage of the event often includes images of the impressive textiles. Participants in the religious celebration may connect the historical arrival of cloth and tiffaifai creation with Christian influences, but, as with other interactions with tîfaifai is a wide range of contexts, individual ideas proliferate. One participant in the 2013 celebration, for example, told me that the tïfaifai, which were mostly of the traditional style with floral designs, served to remind participants of the beauty of the earth, a theme used in the event's programme that year (pers. comm., 5 March 2013).

Messages imparted by tïfaifai displayed in photographs may also be linked with ideas of cultural heritage. In a 2016 publicity photograph promoting 28 November as Polynesian Language Day, the visual juxtaposition of the hosts of Fare Mā 'ohi, a television programme conducted in Reo Mā'ohi, stood in front of a tîfaifai. The image served to emphasise both the language and the textiles as elements of Mā'ohi cultural legacy (Air Tahiti Magazine 2016).

As symbols of Mā'ohi cultural heritage, tïfaifai are potent political statements about identity that can operate outside of French Polynesia. Tïfaifai have been displayed at venues where touring French Polynesian dance groups perform, given to French Polynesian sister cities and donated as political presents to museums. In 2013, for example, two tīfaifai by Emma Tamarii, one of the most highly acclaimed tîfaifai makers of French Polynesia, were included among the items that President Flosse took to Paris to donate to the Musée du quai Branly (Quai Branly Museum) as representative of the superior artisanal work of the people of French Polynesia. The Pōmare Family tableau-style tīfaifai, previously mentioned, is owned by the Queensland Art Gallery, and the British Museum in London owns two Tahitian tïfaifai. When tïfaifai are included in museum holdings outside of French Polynesia, they simultaneously perform the legacy of a rich textile tradition and convey something of Polynesian cultural identities. When tïfaifai are exhibited in international quilt expositions, they can impart the same messages. 


\section{People Performing with Tïfaifai}

Sometimes direct human interaction with a tifaifai is part of the performance of cultural heritage. One of the most significant and early ways in which tīfaifai replaced an important ritual use of barkcloth, the indigenous fabric made by islanders, was in the presentation of a tîfaifai to an honoured recipient by wrapping it around the recipient. Just as islanders once enveloped European explorers in barkcloth, today they encircle high-status people and those honoured for special contributions and achievements with a gift tïfaifai (de Chazeaux and Frémy 2012; Hammond 1986a) (Fig. 7). Tïfaifai bestowed on dignitaries and others carry a heightened message of pride in cultural traditions and Polynesian identities, as well as a personal message for a recipient. When a young Mā'ohi woman won an international title in tae kwon do in 2013, for example, she was honoured for her achievement by the French Polynesian President who bestowed a tifaifai upon her that was wrapped around her body. Couples are sometimes enveloped together in a tïfaifai as part of their wedding celebration. In any wrapping scenario,

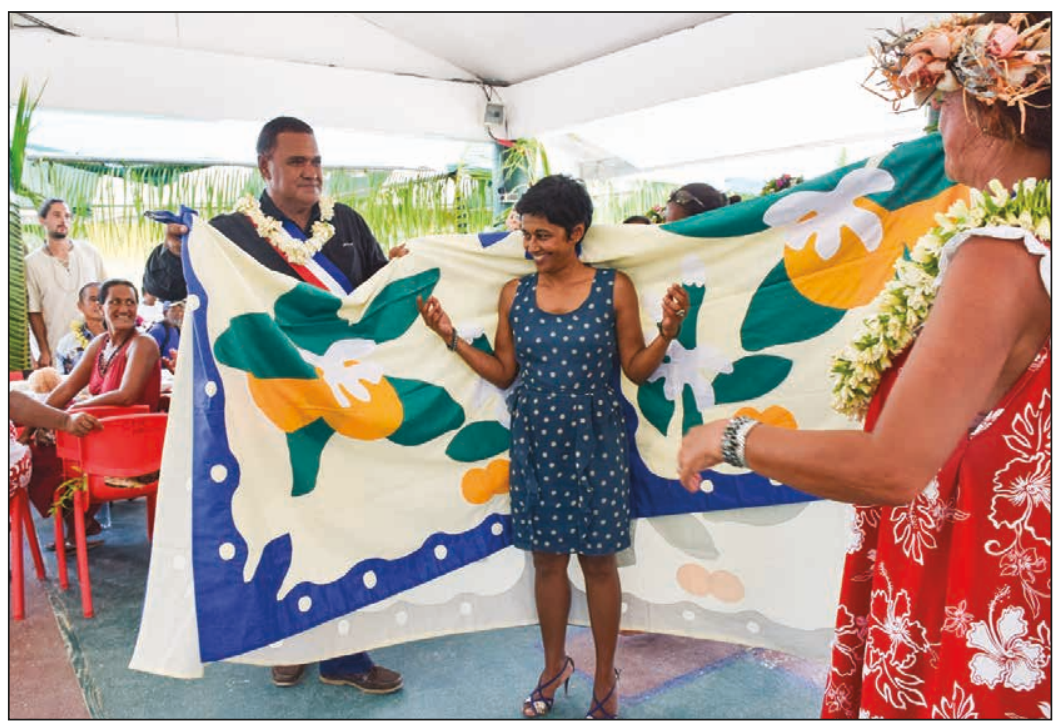

Figure 7. A tîfaifai is wrapped around Ericka Bareights, the French Minister of Overseas Territories who administers all French territories outside of France, on the occasion of her visit to the Tuamotu atoll of Ahe in 2017. Photograph courtesy of Marie Guitton. 
the joyful interaction of donors and recipients is part of the performative aspect. The ongoing public display of tiffaifai in this manner derives much of its power from the fact that it links the present with both the pre-contact and post-contact pasts. ${ }^{11}$

As discussed earlier, a well-known historical practice is that of reserving tïfaifai for use on beds, other furniture and walls of a home for special events or holidays when guests are expected; they are also placed on an overnight guest's bed as a way to respect a visitor. Children learn that family members are not to sit on tîfaifai when the textiles are brought out on such occasions; only an honoured guest can sit on a tïfaifai. Therefore, in July 2017, when a divan was covered with a tiffaifai and placed at one end of the public performance area where awards were announced for the year's annual Heiva celebration of dances and song performances, an expectation was generated that someone would be invited to sit on the tïfaifai. Coco Hotahota, the highly esteemed and ageing director of the dance troupe Temaeva, accompanied by two of his closest friends, was summoned to sit on the tiffaifai to hear praise for his decades of artistic contributions.

Yet another performative, public role in which people directly engage with a tîfaifai and tīfaifai maker(s) is in the demonstration of making tîfaifai. Occasions for demonstrations are sometimes linked with contests, as previously discussed. These contests not only highlight creators' savoir-faire but also, since onlookers can watch the entire process, may encourage others to create tîfaifai themselves or at least purchase a basted one to complete. Occasionally, demonstrations of creating an appliqué tīfaifai occur at Salon du Tifaifai and in the sellers' area of the Tahiti Tourisme building or at other Tahiti Tourisme events.

Other occasions and venues are more pointedly planned with the objective of teaching others how they can carry on a time-honoured tradition. Schoolchildren are sometimes introduced to tîfaifai-making as part of their cultural heritage curriculum (Fig. 8), and adults, as well, have been given opportunities in conjunction with cultural heritage days held at the Musée de Tahiti et des Îles (Museum of Tahiti and the Islands). The demonstrations are sometimes expanded into opportunities for children and adults to perform steps of making a tîfaifai with someone guiding them.

A final example of a performative role with an interactive component comes from a "beauty contest" for older women. In June 2013, a Miss Mama Contest for older women was held in Vaitape, Bora Bora. The rules required that each of the eight contestants present something for a talent section. Most women danced, but one woman, with the aid of her granddaughter, created a tableau vivant 'living scene' in which she sat on a large rattan chair sewing a tïfaifai as her grandchild stroked the grandmother's cheek lovingly. The 


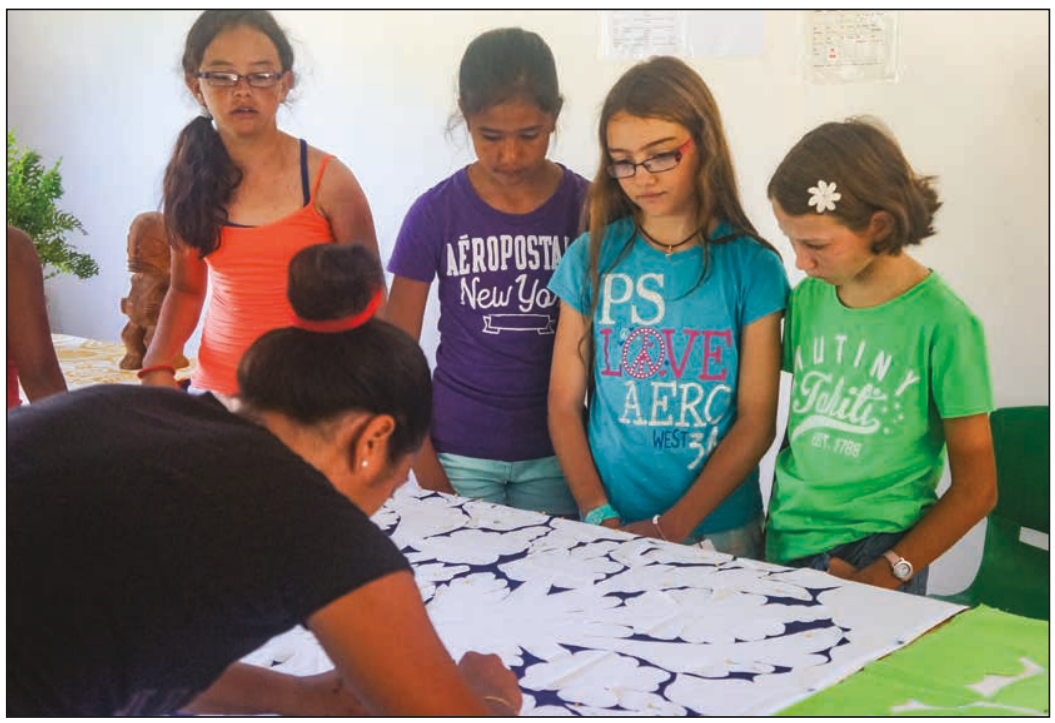

Figure 8. Elementary schoolchildren from École Tuterai Tāne watch a young woman working on a tîfaifai as part of a training program under the guidance of renowned tïfaifai creator Emma Tamarii. The children's visit was part of the Heritage Week programme for their school. Photograph by the author, 2013.

local and mostly older audience knew exactly how to interpret this scene: the tîfaifai was being created to bestow upon the granddaughter at some future date. In a perfect act of art imitating life (the tîfaifai on the stage might well be the tīfaifai intended for the girl's future marriage), the scene communicated the vitality of an ongoing tradition (Fig. 9).

Most of the performances of tïfaifai discussed to this point are primarily for local audiences. The Salon du Tifaifai attracts many people from France who are living in the islands for a few years, but the presence of tourists is rare. However, tourism does provide two scenarios for tïfaifai to perform as cultural-legacy icons. Some small, family-run hotels use tīfaifai to decorate guest rooms or common living spaces to add to the Polynesian ambiance of their establishments. Publications promoting tourism in the islands may also report on tïfaifai as part of Polynesian culture. In 2013, for example, Air Tahiti featured information about Raivavae in the Austral Islands in their in-flight publication. On the magazine's cover was a photograph of Clarisse Paulin, the owner of a newly opened pension who is also a celebrated creator of tîfaifai. In the article, she is shown with the pension's bungalows 


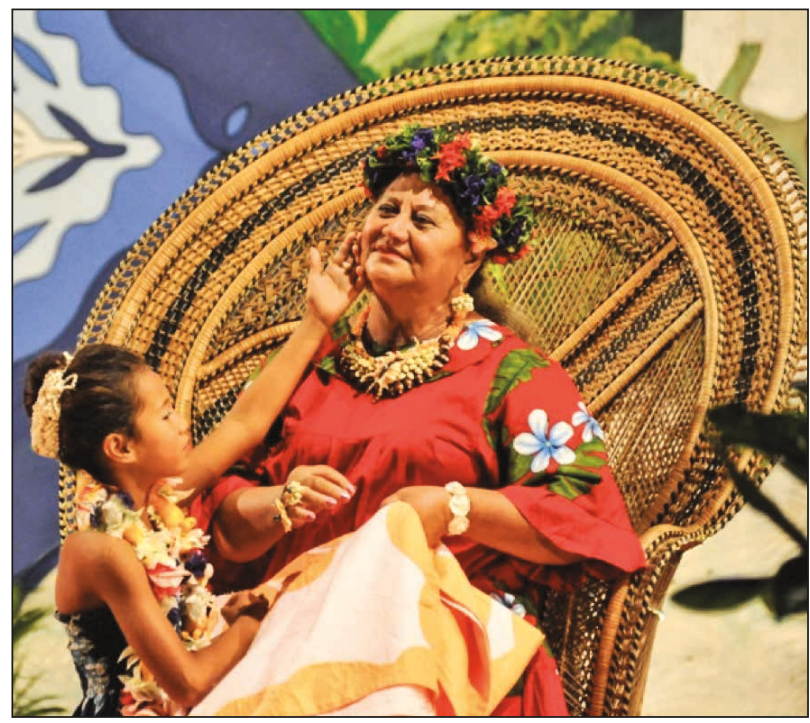

Figure 9. One of the contestants of the 2013 Miss Mama contest in Vaitape, Bora Bora, stages a tableau vivant or living picture as her talent contribution. She sews a tïfaifai as her granddaughter looks on appreciatively. Photograph courtesy of François Bossavit, Loisirs Photo Vidéo.

and the several striking tîfaifai she made to adorn guests' beds. Welcoming and honouring guests by placing a tîfaifai on their beds is an adaptation of a historical family practice within the islands. Extended to tourism, the gesture is one that references and extends a traditional custom, as well as providing Polynesian ambiance for visitors. In contrast, large hotels with many guests forgo placing tïfaifai on beds but sometimes hang one or two on foyer walls as decoration. Large hotels may also offer guests a workshop or demonstration of how to make a tīfaifai in a weekly round of activities that may include lessons on how to dance, how to create a flower garland or how to weave something from pandanus leaves and other activities associated with Polynesian cultural heritage.

With the advent of destination weddings, French Polynesian tourism's creation of "traditional" Tahitian weddings for tourists, begun in the 1990s, provides yet another context in which tîfaifai represent cultural heritage. Based on local practices of wrapping a newly married couple together in a tiffaifai during the festivities of a marriage ceremony, ${ }^{12}$ tourists who purchase certain wedding packages may also be enveloped in a tïfaifai (Hammond 2017). 


\section{A CULTURAL BIOGRAPHY OF TİFAIFAI}

... it remains vital to relate the life of things, in one way or another, to the ways in which people give meaning to them. (Van Binsbergen 2005:19)

Since tîfaifai, like other objects, have agency, they may usefully be considered as having "lives" (Appadurai 1986; Kopytoff 1986). As has been asserted with respect to objects in general, the concreteness of tîfaifai at any time "emerges as a momentary point in a spectrum of making, use and dissembling that constitutes their biographies, their social lives" (Bell and Geismar 2009: 6). A biographical approach that takes into account a "succession of uses and recontextualizations of things" (Thomas 1991: 28), whether applied to a single thing or a category of things, may be examined with questions such as: What recognisable stages or ages define things' "lives"? What marks these stages and how do things change over their lifespans? I am bolstered in my contemplation of the biography of tïfaifai by the fact that Jerry Biret, the son of the renowned tiffaifai maker Virginie Biret, told me about the way in which he and his mother had presented the story of tifaifai and its evolving nature to attendees of an international quilt conference in Canada (pers. comm., 29 May 2013). The mother and son took several tîfaifai with them to show as they explained how tīfaifai had changed over the decades in terms of methods of construction, popular styles, variation in sizes, motifs, colour selection and other visible changes.

In what follows, I discuss what I consider to be three significant stages in the lifespan of tîfaifai as a genre of islanders' material culture. Although I include some information about the ways in which the textiles' appearance has changed (for more detailed information see de Chazeaux and Frémy 2012; Hammond 2014, 2015), I discuss those and other changes in the context of ways in which the social, economic and political changes in the islands of Eastern Polynesia have affected and continue to affect how islanders use and value tîfaifai in public spaces and events tied to a discourse of cultural heritage. Owing to the co-constitutive nature of people and the textiles, tîfaifai have shaped people's thinking, actions and identities at the same time that societal changes have influenced the ways that people constitute tîfaifai within profound changes of the last century and a half.

\section{From Origins to the 1970 s}

In his 1991 book Entangled Objects: Exchange, Material Culture and Colonialism in the Pacific, Nicholas Thomas wrote of the interest that Pacific Islanders and Europeans who encountered one another in the 18th and 19th centuries had for particular objects associated with each other's cultures. Western cloth and Western clothing were among the gifts bestowed or goods traded by Westerners with indigenous people. Polynesians welcomed and 
appreciated Western cloth for its colours, printed designs and durability. Küchler et al. (2005: 84) have also suggested that islanders were inspired by Western cloth's luminosity and sought to capture a special efficacy they considered it to have.

For their part, Europeans received large quantities of indigenous barkcloth as gifts from the elite of Tahiti. Scholars aboard Cook's voyages of scientific exploration recorded information about the indigenous fabric's appearance, manufacture and uses, and, since European explorers were given barkcloth, often in large quantities, some was transported to Europe as objects of scientific interest or items of "curiosity". Notable among Westerners' early observations was the fact that women of high rank took as much pride in making barkcloth as those of lower social levels, and members of the chiefly class commandeered the greatest quantities of barkcloth of the best quality. As in other areas of Polynesia, the finest barkcloth in the Society Islands was strongly associated with sanctity and was a symbol of wealth and prestige (Rose 1971; Tcherkézoff 2003, 2004). Islanders' practices of wrapping god figures and deceased members of chiefly rank in barkcloth was noted, and some of the officers on ships were honoured by being wrapped in barkcloth.

In the late 18th and early 19th centuries, both barkcloth and Western cloth existed in the Society Islands. As D'Alleva (2005) has noted, islanders' clothing sometimes combined the two. However, the manufacture of barkcloth slowed, and by the middle of the 19th century it was no longer being produced (Koojiman 1988: 22), owing to such factors as the advantages of Western cloth's durability, the prestige value of Western cloth, the destruction of wooden sculptures clothed in barkcloth and the association of Western cloth with Christianity.

Quilts, prized articles of domesticity introduced into the Pacific by Christian missionaries and likely spread, in some cases, to other Polynesian islands by Christian converts (Herda 2011: 65), inspired islanders in the Tuamotu Islands, the Austral Islands and the Society Islands to create quilt-like textiles from Western cloth. While these textiles shared much in common with Western quilts and fulfilled missionaries' expectations of useful feminine work and adornment of homes, they differed in form (lacking batting and quilting stitches), and their creation blended former barkcloth-work patterns and some ritual uses of barkcloth with the cachet of imported cloth and Western quilts.

There is no documentation to definitively establish piecework tïfaifai, made by sewing many geometrically shaped pieces of fabric together to create designs, as preceding appliqué tĩfaifai. This is, however, a widely held opinion among people in the Society Islands and is bolstered by a translation of the word tifaifai, usually translated as 'to patch repeatedly', since the word has a long history as a generic term to refer to both piecework (tïfaifai $p \bar{u}$ ) and appliqué styles (tîfaifai $p \bar{a}$ 'oti). Joining small pieces of cloth to 
create a textile was probably the first, or at least primary, style of tïfaifai. ${ }^{13}$ Appliqué tīfaifai, made by cutting out designs to be placed on a background of contrastive coloured cloth, may have been created nearly as early as the piecework style or soon thereafter. Over time, the piecework style has been created far less often, especially in the Society Islands, primarily owing to the time-intensive labour for completing such textiles. ${ }^{14}$

Accounts and photos of tiffaifai from the 19th and early 20th centuries confirm a long history of prestige associated with tiffaifai. In some ways, the textiles extended important uses of barkcloth as gifts and as bed coverings. Utilised as decoration in homes for Christian holidays and in other structures for gatherings and weddings (Cumming 1877; Cuzent 1860), tīfaifai also instigated some transformations in the social environment. As articles of value to be displayed in photographs with people (O'Reilly 1975), for example, they participated in the construction of new social circumstances. These elements constituted early innovations in the tiffaifai tradition.

As a syncretic form combining elements of both Western and Polynesian textile traditions, it is not surprising that islanders incorporated novel designs associated with things and places outside of their region, indicating an early tendency in the life of tīfaifai to embrace the new. Cuzent (1860) remarked on Prussian, Russian and French imperial eagle designs that she saw on tïfaifai in 1858. Lovina Chapman, the daughter of a sea captain, brought Hawaiian quilts to the Society Islands in 1899 (possibly the first time these textile "cousins" were viewed by Mā'ohi) which, according to Hututu Salmon, created great interest (O'Reilly 1959: 167).

In his 1959 work, O'Reilly discussed the ongoing importance of tîfaifai to islanders. The combined meanings of value attached to tïfaifai as prestigious articles associated with Christianity and Western quilts (and the ways in which they extended aspects of barkcloth creation and use) undoubtedly contributed to the ongoing popularity and significance of tïfaifai. Like Westerners writing in the 19th and early 20th centuries, O'Reilly reported mid-20th century on the ongoing use of tiffaifai to adorn houses for special occasions, to serve as decoration during celebrations and to be bestowed as gifts. He also noted the kinds of motifs popular for applique tîfaifai, the most prevalent style in the Society Islands in mid-20th century (as it continues to be today). He cited many floral and plant motifs connected with the island environment, but he also discussed motifs not associated with the islands' setting, such as a Louis XVI basket or the Cross of Lorraine (O'Reilly 1959: 170). Some of the designs for the piecework style of tiffaifai were, he argued, personal adaptations of tapestry popular from the Second Empire period of France (1959: 172). Contests for creating innovative designs for tïfaifai encouraged what has since become a strong, ongoing element within the tîfaifai biography - that of a constant encouragement to innovate. 
In 1977-78, during my own early research on tïfaifai, many people told me about the importance of bestowing tīfaifai on family members and esteemed others, and I saw the continued presence of tïfaifai as decorations inside homes for New Year's festivities and in the construction of a temporary wedding feast house. I also saw parade floats to celebrate the French national holiday (Bastille Day) that were decorated by women from the Austral Islands with their piecework-style tïfaifai (Hammond 1986a). Most of the designs of Society Islands appliqué tīfaifai I saw were variations on the floral and plant designs mentioned by O'Reilly. Garlands of tiare Tahiti flower designs were very common. Some motifs were of peacocks or objects such as hanging lamps and fans. I also saw a few tïfaifai with mermaids and those with symbols of Joseph's Dream. In short, much of what I witnessed in the late 1970s varied little from what I had read of tîfaifai makers and tïfaifai in O'Reilly's 1959 publication. However, in Pape'ete, I heard of and visited the workspace of a woman who had started a small cottage industry of machine-sewn tïfaifai to sell. She employed a handful of young women, including some of her daughters.

The first 120-year span in the biography of tiffaifai, for which very little documentation exists, can perhaps best be characterised as innovatively combining elements of the past with the changing circumstances brought about through the interactions of islanders with Western explorers, traders and missionaries. Tiffaifai were seemingly appreciated for the ways in which they combined values and some uses of indigenous barkcloth with introduced Western cloth and quilts. They were highly valued products employed for a variety of purposes, some associated with public appearances as decoration and gifts, but the vast majority associated with the domestic sphere of creating and gifting tîfaifai for important rites of passage and decorating the home for guests, particularly for Christian holidays. ${ }^{15}$ While women (and some men) made both piecework-style and appliqué-style tïfaifai in many of French Polynesia's islands, in the Society Islands the appliqué style was predominant by the 1950 s if not earlier.

\section{The 1980s to 2000}

In contrast to the first two-thirds of tifaifai's documented history, the 20-year period of tiffaifai from the 1980s to 2000 may be characterised as one of extensive changes, owing to major economic, political and socio-cultural factors affecting French Polynesia. The impetus for many of those changes can be traced to the events of the 1960s and 1970s; therefore, a few facts leading up to the 20 -year period provide information about the ways in which different influences combined.

In its dominating role as coloniser, France positioned itself to make decisions that were to eventually affect all islanders and residents of the 
five archipelagos that became French Polynesia. In the mid-1960s, France's decision to undertake nuclear tests in the Tuamotu Archipelago led to profound changes. The tests, conducted between 1966 and 1996, brought an influx of French military personnel and their families to French Polynesia. Infrastructural changes needed for the "urban-military complex" (Finney 1979) generated jobs, and Pape "ete, Tahiti, the largest city of French Polynesia, began to attract people living on other islands of French Polynesia who sought wage labour and an urbanised way of life. Consumerism increased, not only because there were more goods and services but also because many people from other islands had no ancestral lands to cultivate on Tahiti.

The amplified presence of the French military, the highly controversial nuclear tests, a growing resentment of French-imposed rules and regulations, and the political actions of other Pacific Islanders once colonised by European nations all contributed to intensified political dissent and strife in French Polynesia. With the support of Greenpeace and other international organisations, islanders' protests of the nuclear tests preceded France's decision to grant limited autonomy to French Polynesia in 1977, increased in 1984. In 2003, French Polynesia became an overseas collectivity of the French Republic and the following year was granted administrative autonomy.

Alongside the turbulent political events of the mid-1960s and the 1970s, a renaissance of indigenous Mā'ohi culture began to emerge, led by a number of Tahitian intellectuals who sought to ensure continuation of their Polynesian language and to resurrect various cultural practices such as tattooing, a practice abandoned under the influence of Christianity (Saura 2008: 59). Other cultural revitalisation actions in the Pacific also inspired islanders of French Polynesia. In 1976, for example, the Hokule 'a, a recreated Polynesian voyaging canoe, sailed from Hawai' $i$ to Tahiti with traditional navigational techniques. Noteworthy milestones in French Polynesia included the 1974 establishment of the Académie tahitienne (Tahitian Academy), later named Fare Vāna'a (a Reo Mā'ohi name meaning 'house of oration or discourse') to safeguard and promote the indigenous language; the 1977 establishment of the Musée de Tahiti et des Îles, also called Te Fare Manaha; and the 1981 date when Reo Mā'ohi began to be taught in schools. In 1985, a year after French Polynesia received limited autonomy, the annual festival of dancing, singing and sports, formerly celebrated as France's national holiday, received the name Heiva, a renaming that emphasised the celebration as a Polynesian event and signalled the growing expression of pride in Polynesian identity.

In an interesting synchronistic effect with what was occurring in French Polynesia, the 1960s in France were also associated with a rural-to-urban shift in population. This, in turn, resulted in an expanded understanding of what constituted cultural heritage (Poirrier 2003). France's heritage consciousness began as early as the 1800 s, but it was narrowly defined and 
primarily centred on the preservation of monuments. However, in the 1960s under André Malraux, France's first Minister of Cultural Affairs, a general inventory of France's monuments was accompanied by an accounting of artistic treasures. The inventory, undertaken by hundreds of local voluntary workers, resulted in an expanded and broadened view of what should be counted as part of heritage. In the late 1970s under the government's Ministry of Culture and Communications, an understanding of heritage emphasised a close interrelationship between past and present and opened heritage to an ethnological approach that included local practices, skills and objects.

The new approach, later adopted by the French Polynesian government in congruence with the enlarged view in France, strengthened incentives to retrieve and practice some past traditions. In contrast to reintroduced cultural practices of the mid to late 20th century in French Polynesia, the creation and use of tîfaifai did not have to be resurrected as a cultural form. Some tīfaifai expositions and contests were staged before the 1980s, often in conjunction with the July festivities established in 1881 to celebrate the French national holiday, but the increased emphasis on artisan activities beginning in the 1980s ushered in an era of artisan centres and more competitions in crafts, including tīfaifai. The emphasis on cultural heritage also supported efforts to recognise the skills and knowledge needed for creating tîfaifai, as well as the significant roles tīfaifai had always played in Mā'ohi culture. Including tîfaifai in the discourse of le patrimoine or faufa 'a tupuna helped to affirm the significance of the creation and use of the textiles in terms of Polynesian identity and cultural pride.

Some of the most profound changes for Tahiti during the latter part of the 20th century - ones that impacted other islands of French Polynesia as well-strengthened a continuation of the tîfaifai tradition, albeit with changes (Hammond 2014). In the challenging economic milieu of increased wage labour and population growth in Pape'ete, the global economic crisis of 1987 and an economic downturn that accompanied French withdrawal of the nuclear testing programme, many islanders sought new sources of revenue. Alongside the ongoing creation of other arts and crafts, many of which were attractive to tourists, more islanders turned to selling tïfaifai to other islanders and those continental French living in the islands for several years. For some women, this became part of a strategy for their families' economic well-being (Langevin 1990: 92). The commercialisation of tîfaifai in the latter part of the 20th century led to more machine-sewn tīfaifai, sometimes with simplified designs to reduce sewing time. In turn, the increased sale of local tïfaifai to islanders and mainland French led to importations of commercially produced tïfaifai-inspired textiles made in factories in Southeast Asia. These were sold at much lower prices than locally made tïfaifai. 
Influenced by all these changes, three significant developments can be noted in the biography of tiffaifai, all of which were strengthened by the growing cultural heritage discourse occurring in French Polynesia. The three developments cast tîfaifai in a stronger public, performative role to celebrate and safeguard tïfaifai made in French Polynesia, and all three developments were supported by the French Polynesian government. As Dicks points out, "[t]hrough display sites, people can ensure their own traditions continue, ones which might otherwise be lost, by educating people about them" (2003: 13).

The first major development occurred in the 1980s when some of the leaders of women artisans' cooperatives began to challenge tîfaifai makers to create new work. Since many contest themes encouraged the creation of pictorial scenes, the colourful tableau-style tiffaifai came into being. As detailed earlier, many of the themes associated with expositions and contests have highlighted what are considered traditional aspects of island life, whether in the form of resources, cultural practices or both. Older tïfaifai designs are now frequently regarded as a way of remembering and honouring the cultural heritage of the tîfaifai tradition itself.

The second major development, the 1997 exposition of tiffaifai entitled Un siècle de tifaifai (A Century of Tîfaifai), was a watershed event. The third major development was the creation of Te Api Nui O Te Tifaifai, built on the momentum of emphasising tīfaifai as cultural heritage objects. Both the second and third developments resulted in what may be described as consciously shaped heritage stances, cast within what Fienup-Riordan calls "conscious culture" (2000: 167) and Appadurai calls "culturalism" (1996: 14-15). Such heritage actions are often performed in both old and new public contexts as a response to demands and changes originating both inside and outside of indigenous communities. They may serve to mediate new circumstances and support communities' unique identities.

Documentation exists for some public displays of tïfaifai in contests, church bazaars and sale exhibitions for decades before the annual artisan competitions established in the 1980s as part of the Heiva Rima' $\overline{1}$, previously discussed, and the creation of the 1997 exposition Un siècle de tifaifai (de Chazeaux and Frémy 2012; Hammond 1986; O’Reilly 1959). However, the 1997 event, mounted by the French Polynesian government's Ministry of the Economy and of Artisans, in collaboration with Tahiti i te Rima Rau (a committee of traditional artisans), put tiffaifai squarely before the public as treasured objects and a designated part of French Polynesian cultural heritage. The attention to the longevity of the tiffaifai tradition in the exhibit's collection (a few of the textiles dated to the 19th century and others represented the decades up through the 1990s) and the inclusion of both piecework- and appliqué-style tîfaifai signalled a historical, museum- 
like retrospective. Some of the exhibited textiles were family heirlooms that had never been publicly viewed, a notable component of the exposition since many tïfaifai patterns were not (and are still not) shared outside of families. The familial aspect of the exhibit conveyed a message that the treasures of tiffaifai were a part of not only family patrimonies but of the society's cultural heritage at large. Also significant was the fact that the tiffaifai were not for sale, conveying the message of the collection as a public heritage to be appreciated and acknowledged.

The exhibit was followed with a book, Tifaifai: The Tahitian Patchwork, which featured some of the exhibit's tîfaifai. Referring to the anticipated book in 1997, Georges Puchon, the Minister of the Economy and of Artisans, declared, "Thanks to this work, we can say that we are going to safeguard this cultural heritage which remains so living and creative" (Durocher 1997: 26). In the book's introduction, written by Gloaguen and Chin Foo, tîfaifai are identified as a family heritage that is "the memory and the expression of a feminine cultural identity". The authors also observe that "[a]s a substantial source of income today, the tifaifai must remain an original adornment item made with taste and perfection. It would be wise to protect it like other art creations" (Gloaguen and Chin Foo n.d.: 7).

The book's text was written in French, English and Japanese. The three languages highlighted the fact that tiffaifai were not only attracting interest among French citizens living in France or those who came to the islands but also gaining a widening international following, especially among Japanese. In addition to including the specific names of the tîfaifai designs (usually in both Reo Mā'ohi and French), the book included large colour photographs and information regarding each tīfaifai's design, age and other details. At the back of the large-format paperback, a pattern for creating a traditional appliqué tīfaifai was included, as well as a list of contacts for readers who wished to find tîfaifai in the islands.

The creation of Te Api Nui O Te Tifaifai, the third significant development for tîfaifai's role in le patrimoine, was largely triggered by an increasing threat of imported tīfaifai undermining islanders' economic efforts to supplement their income by making the textiles, as well as the recognition that factory-produced, machine-sewn tîfaifai could lead to a deterioration in the quality of local tîfaifai. Organisers of Te Api Nui O Te Tifaifai created the association devoted specifically to tïfaifai and borrowed the French Polynesian government's mantra of promoting, protecting and valuing cultural items and practices - in this case, locally made tîfaifai.

The most visible work of Te Api Nui O Te Tifaifai since the organisation's inception has been their annual two-week salon. Early in the organisation's existence, the members decided to purchase a particularly fine tiffaifai entered 
into the contest each year in order to establish what they refer to as their Patrimoine Collection (Fig. 10). Some of the collection is displayed for special occasions. In 2013, for example, several were mounted for the first Festival of Traditional Artisanship. Others were hung at the 2013 Salon du Tifaifai in commemoration of the association's 15th anniversary. Some have travelled with members of Te Api Nui O Tifaifai to expositions outside of French Polynesia. It is the organisation's plan to safeguard the collection for the public's education and the possibility of a future permanent place to house them.

The 1980s to the year 2000 were a significant stage in the biography of tïfaifai, primarily due to the events that led to foregrounding tîfaifai as part of islanders' cultural heritage. The social, economic and political changes that ushered in islanders' efforts to secure greater political autonomy from France, achieve economic viability and embrace cultural revitalisation were factors that influenced tîfaifai's emerging role as cultural heritage objects. In this capacity, individual tîfaifai and tîfaifai that are primarily associated with the private, domestic realm are considered to be part of people's cultural heritage, as illustrated by the remarks of two staff members of the Government Office of Traditional Arts and Crafts as recorded in my fieldnotes for 23 April 2013:

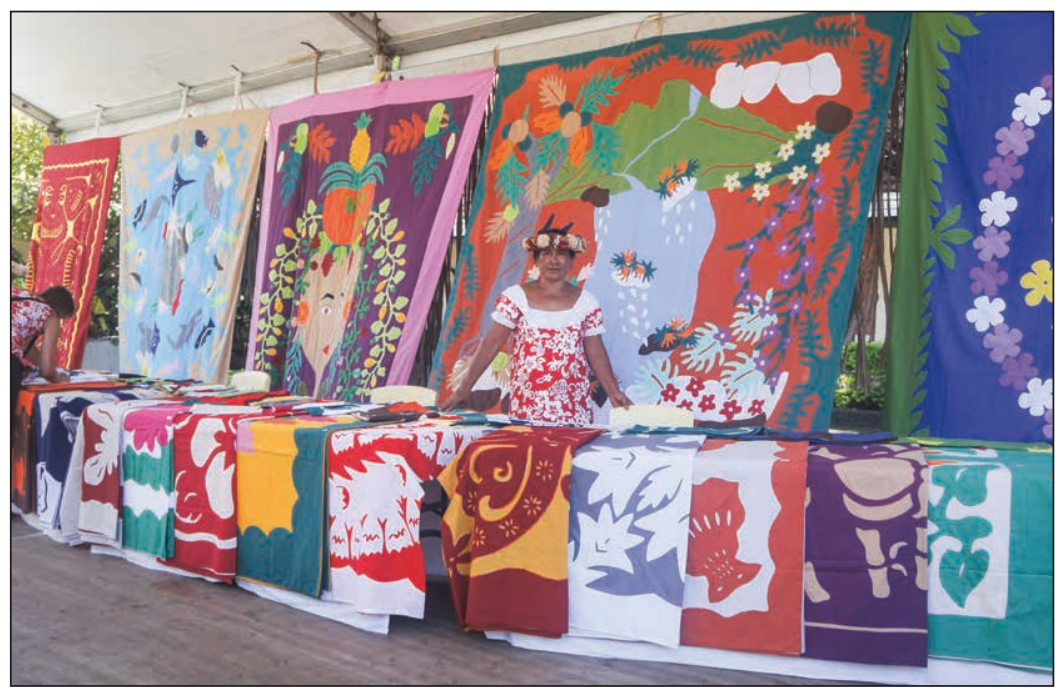

Figure 10. The hanging tîfaifai are part of Te Api Nui O Te Tifaifai's Patrimoine Collection, exhibited here in 2013 at the first Festival of Traditional Arts. Unlike the folded tîfaifai on the tables, the tîfaifai of the heritage collection are not for sale. Photograph by the author. 
"It [a heritage object] is something of the ancestors and something to pass to future generations. It is like a jewel, very precious. If there is not a perpetuation of tradition, it will rupture." To illustrate this, she [the staff member] asserted that she will pass on her tiffaifai to her children as patrimoine. To my question of whether someone can create a patrimoine object today, the response was a definite affirmative. As illustration, another one of the staff members said that if one did not have such things in the family before, one could create them now. This suggests that cultural heritage is associated with certain practices and phenomena that have existed in the past, but that new manifestations of behaviours and things are not only acceptable but desirable in order to keep a tradition alive.

More visibly than tîfaifai kept in homes, tïfaifai in the 1980s to 2000 were taking a larger role as items of cultural heritage in public displays. In this capacity, they began performing cultural heritage of the tifaifai tradition itself, and, by extension, cultural heritage as a whole, often through specific tīfaifai motifs.

\section{0 to The Present}

As the present century began, tîfaifai's public performative roles increasingly encapsulated messages about cultural heritage, a development that reflects Brett's (1996: 8-9) assertion about the ways in which people may strive to recover a sense of the past and re-establish values and revitalisation practices in the wake of major changes in their society that have eroded former ways of life and traditions. People's agency, often in combination with the agency of things, may be used to recall and rearticulate the past as part of identity politics. As concrete objects, tïfaifai, like other textile traditions, are historical records that "capture diverse or distinctive cultural traditions and thereby serve collectively to help present the past" (Warren 2000: 68). Within the process of conscious culture or culturalism, tïfaifai performances in public spaces and events have coincided with other culturalism developments, such as the 2001 reintroduced fire-walking ritual that has become an annual event on Tahiti and staged reenactments of chiefly rites on Marae 'Ārahurahu in Paea, Tahiti, developed in the first two decades of the 21 st century. ${ }^{16}$

Acknowledging that the connection between heritage and identity is well established (Smith 2006: 48), Smith (2011: 80) has also observed that "[ $\mathrm{h}]$ eritage is a cultural process or performance that is engaged with the construction and reconstruction of cultural identity, memory, sense of place and belonging". According to her, memory is an important constitutive element of identity formation that can be particularly powerful as it "takes root" in the concrete (2006: 60). Yet the "concrete" is not unchanging. Wettstein (2016: 391) points out that a "'manifestation of identity' in material culture and performative events should not be understood as a fixed, static state, but can be seen as a process in permanent flux". 
In 2010, when I returned to French Polynesia to learn of changes in tîfaifai creation and use, some of the special purposes that linked tiffaifai with specific barkcloth traditions, such as wrapping honoured recipients in a tîfaifai, were ongoing, but often consciously contextualised within the discourse of cultural heritage. This is particularly evident in tourists' "traditional" Tahitian weddings with a tīfaifai wrapping. There were also new venues for the textiles, as detailed in the first part of this article, and an enlarged emphasis on promoting the skills of tiffaifai-making to ensure the continuance of an established tradition. The French Polynesian government's support of tîfaifai expositions, pedagogical projects with tîfaifai and the gifting of tiffaifai to organisations outside of the islands has bolstered and contributed to the cultural heritage discourse.

An increase in media coverage about tîfaifai creation and use has also contributed to an expanded performative role of tîfaifai in cultural-heritage discourse. The monthly French Polynesian government publication, Hiro 'a, Journal d'informations culturelles, has featured several articles about tîfaifai. In 2012, two books were published in Tahiti about tīfaifai and tïfaifai artisans (de Chazeaux and Frémy 2012; Grand 2012) that have contributed to tîfaifai's association with cultural heritage.

Tifaifai mounted temporarily or permanently for public display are largely seen by island residents, not only people of Mā'ohi descent but people of other ethnicities living in French Polynesia as well. French people from continental France who move to French Polynesia for several years in conjunction with jobs are exposed to tīfaifai in local media and may see tïfaifai in expositions and other contexts. They often develop an interest in the textiles and are knowledgeable about the great value placed on tiffaifai by people of indigenous descent. According to tîfaifai makers, French people from mainland France are the main purchasers of tableau-style tiffaifai that incorporate subject matter of traditional island lifeways and island resources. Many people from mainland France purchase tîfaifai to take home as souvenirs of their sojourns in French Polynesia and to give to family and friends.

Some residents in the islands who are not indigenous have learned to make tīfaifai or buy basted tīfaifai which they complete. Michèle de Chazeaux and Marie-Noëlle Frémy, residents of Tahiti and authors of Le Tifaifai (2012), told me that during the years when the French military presence was strong, many wives of soldiers wanted to learn to make tïfaifai. Their interest contributed to the general revitalisation of interest in tîfaifai among locals (pers. comm., 20 February 2013). In a sense, therefore, tïfaifai have come to be regarded as part of a cultural heritage which all residents may share.

Tourists, on the other hand, who typically visit for two weeks or less, may never see tîfaifai unless they stay at a hotel displaying the textiles, attend an exposition during their trip, encounter images of tiffaifai in the media or go to Tiki Village on Mo'orea where various arts are demonstrated. However, 
a very recent development may ensure that most visitors can see a tîfaifai during their visit. In March 2018, a new display of "objets du patrimoine polynésien" (Polynesian heritage objects) (Hiro'a, Journal d'informations culturelles 2018), including a magnificent red and white traditional appliqué tïfaifai with a breadfruit design, was placed in the arrival area at the Tahiti airport. Miriama Bono, Director of the Museum of Tahiti and the Islands, is quoted in the Hiro 'a publication as stating, "The idea is to show the evolution of heritage with a dynamic and contemporary vision" (Hiro'a, Journal d'informations culturelles 2018).

Tïfaifai makers repeatedly told me that tourists do not purchase tîfaifai, even if they see them being sold in an exposition. Although this may be partly due to a lack of exposure and knowledge of the significance of tîfaifai to islanders, the artisans also attribute it to the expense associated with tiffaifai (especially those hand-sewn) and the textiles' size and weight. Thus, unlike many arts that have experienced a revival based on societies' tourism, tîfaifai's efflorescence in the present period has not been driven by tourism. There are, however, people from around the world who connect with tîfaifai artisans and order from them. Some of these connections are made in person; others are negotiated over the internet.

That tiffaifai are regarded as part of le patrimoine and communicate that message beyond the boundaries of French Polynesia may be witnessed in the acquisition of tiffaifai for international museum collections and in the depiction of tifaifai on several postage stamps issued by the French Polynesian government and on the websites of some tîfaifai makers. While such phenomena instruct others outside of the islands about a link between cultural heritage and tiffaifai, it is common knowledge within the islands that tiffaifai have always been cherished. The skills and the textiles themselves have been literally handed down from one generation to another and interpersonal relationships celebrated with tîfaifai bestowed as gifts. The co-constitutive elements of tïfaifai and indigenous islanders continue to manifest themselves in how highly people value the textiles, the renown bestowed upon expert makers for their artistic talents and fine sewing skills, and the deep emotion communicated between those who give and those who receive tiffaifai.

In the period of 2000 to 2018, tîfaifai have "taken centre stage" in public places and events as cultural heritage objects linked with cultural identities. Building upon the foundational three events of the late 1990s-1) the themedriven tîfaifai competitions that ushered in tableau-style tîfaifai, 2) the $U n$ siècle de tifaifai exhibit which definitively rendered tîfaifai as cultural legacy objects (thereby identifying creators in the co-constitutive roles as cultural heritage creators), and 3) the establishment of Te Api Nui O Te Tifaifai, the association that emphasises tïfaifai as part of islanders' cultural heritagetïfaifai makers and tïfaifai themselves continue to co-construct each other within the cultural heritage discourse. 
From the origins of tîfaifai, involving adoption of Western cloth and selected aspects of both Western quilts and Mā'ohi barkcloth traditions, to the first creations of tîfaifai motifs that expressed islanders' celebration of their environments as well as ideas and objects acquired from abroad, to the more recent innovations of selling tīfaifai and creating tableau-style tîfaifai, changes in the tiffaifai tradition are a result of islanders' choices and decisions made in response to social, economic and political changes. The ways in which traditions persist by combining old and new have been articulated by many scholars including Clifford (2001), D’Alleva (2005), Hermann (2011), Kaeppler (2008) and Stevenson (1990, 2002). Despite all of tïfaifai's ties to the past, innovation has always permeated the tifaifai tradition. However, the changes of the past 40 years in French Polynesia have resulted in islanders actively shaping some practices in the tîfaifai tradition that are consciously crafted assertions of Polynesian pride and identity expressed through cultural heritage. Over the past eight years, many islanders have told me that it is necessary for tiffaifai to change, progress and develop. They use the French word évoluer (to evolve, to change), pointing out that, like society itself which is undergoing transformations, the tîfaifai tradition should be expected to change. The new and the old are often combined though tîfaifai, ultimately forging a message that the past, present and future are all connected.

Just as people have constituted tiffaifai, so too have tïfaifai shared a role in shaping islanders' identities. Dicks (2003: 126) notes that "heritage displays offer a space for the intertwining of public, exhibitionary space and private, biographical space". The retention of some elements of tiffaifai's past and the commitment to being open to future change is part of a widely held islander view of the contemporary tîfaifai tradition. Benjamin Rangivaru, one of the exposition participants in the 2014 Salon du Tifaifai, told me that he never repeats a design he makes, a practice increasingly shared by many tîfaifai artisans today. Reflecting on present and future changes within the tîfaifai tradition, Rangivaru asserted that to retain the symbolic nature of tiffaifai, "You have to return to your own culture and all the meanings of handicraft, social relations, and heritage that you want to transmit to children. ... The work of tīfaifai is not superficial. It's connected to my culture, to my personality, to my origins, to my language and to my identity. It is a heritage." At another point in our conversation, Rangivaru stated, "For me, tïfaifai is culture and identity. I am still reflecting on it. It is our roots and our culture. It has a symbolic signification. Tïfaifai is the symbol of true social relations because before [in its early history], tîfaifai was not made alone. A second signification is that the tiffaifai unites: for example, in the envelopment of a 
couple in marriage" (pers. comm., 30 April 2014). Rangivaru's statement exemplifies Miller's observations about the ways in which the things that people make make people (2005: 38). His comments also illustrate "the vitality of material forms and how things embody, inculcate and represent people's ways of thinking about the world" (Bell and Geismar 2009: 4).

Given the significance of tiffaifai within the larger discourse of cultural heritage in French Polynesia, it is ironic that the way in which islanders understand the tiffaifai tradition as wholly authentic and integral to their cultural heritage is in contradiction to the absence of tiffaifai in many books that feature what their authors identify as traditional Pacific arts. ${ }^{17}$ This is presumably because tīfaifai are not cultural objects that can be traced to a "pure" tradition predating Western contact and because tīfaifai incorporate cloth manufactured outside of the islands that was introduced by Westerners. For islanders, the concepts of threat and risk for tiffaifai are not about needing to preserve specific past practices of tîfaifai (for example, in terms of sewing widths of fabric to create a textile of desired dimensions). Rather, they centre on allowing tîfaifai to evolve with the times and preventing the usurpation of locally made tifaifai, particularly hand-sewn textiles, by machine-sewn and mass-produced tîfaifai created in Southeast Asia. As islanders sometimes pointed out to me, the imported textiles cannot embody the same spirit as those created by islanders who know the rich and varied meanings that tïfaifai convey.

From the time they were first created, tiffaifai have been an integral part of the lives of islanders in French Polynesia. As a vernacular art form, anyone, including men, could make tîfaifai. For many people, the textiles are still primarily associated with the home and expressive of familial ties, but over the past 30 to 40 years, tiffaifai have increasingly expanded their roles in public spaces and events. As detailed in this article, most of the places and events where tîfaifai are displayed are ones that are primarily associated with locals, a clear indication that tiffaifai are very meaningful to islanders. By framing older "classic" designs of tîfaifai as part of a cultural legacy that should be preserved, promoted and protected, sometimes through contemporary replications, and, at the same time, forwarding the more narrative tableaustyle tïfaifai as part of an ongoing tradition, one in which creators often choose to fashion scenes depicting islanders' past ways of life, legends and valued island resources, the tîfaifai cultural heritage discourse becomes all inclusive. Even those designs that are not associated with the Polynesian past (e.g., a tîfaifai made to look like a postage stamp featuring a cherry tree design, the "at" symbol @, or a design based on a greeting card with a picture of swans) can be incorporated into a tîfaifai tradition of cultural legacy because they exist as tîfaifai. As Clifford (2001: 475) has pointed out, "[t] raditions articulate, selectively remember and connect pasts and presents". 
The increased public role of the textiles in discourses of cultural heritage, I have argued, is linked to the biography of tiffaifai as a tradition. It is a history that includes the entwinement of tïfaifai with such societal changes as the augmented numbers of French citizens from mainland France living in the islands; the urbanisation and economic changes that ushered in more waged labour jobs; the political impact of France's nuclear tests in French Polynesia; the Polynesian cultural renaissance, greatly supported by the French Polynesian government, with its emphasis on arts and crafts, music, dance and indigenous language; the influence of French heritage policies; the establishment of an organisation devoted exclusively to tîfaifai; and globalisation forces such as less expensive imported tîfaifai made outside of the islands.

Recognising the co-constitutive nature of tiffaifai with the people who create them and others involved with tïfaifai in various capacities reveals that "[m]eanings are not in the materiality of things, but rather in how things are constructed as meaningful in social practices of representation" (Storey 2017: 18). There is, as Storey (2017: 17) observes, "a simultaneous entanglement of meaning, materiality and social practice". In French Polynesia, tîfaifai now enact many roles in the discourse of cultural heritage: celebrating Polynesian cultural continuity, including the intangible heritage practices of honouring people by wrapping them in tïfaifai and passing on knowledge and skills for making tïfaifai; communicating information about cultural values and expectations; shaping cultural identities; commemorating historical events; and relaying information about Polynesian ways of life. Individual tīfaifai or collections of tïfaifai placed on permanent or temporary public display often perform several of these roles at once. The proud assertion of a unique past supports islanders' present efforts to claim and assert a strong Polynesian identity.

\section{ACKNOWLEDGEMENTS}

I am very grateful to the people of French Polynesia who generously shared information, assistance and encouragement. To the officers and members of Te Api Nui O Te Tifaifai, the director and employees of Le Service de l'Artisinat Traditionnel de Polynésie française, the staff of the Archives territoriales de Polynésie française and Vera Lacombe, Principal of École Tuterai Tāne, I extend my heartfelt thanks. I also wish to acknowledge the support of Western Washington University and my colleagues and the staff at the Department of Anthropology. 


\section{NOTES}

1. The word tîfaifai is used as both a singular and a plural in this paper. In the indigenous language of Tahiti, an article preceding the word specifies whether it is singular or plural.

2. See also information on Tongan quilts in Herda 1999, 2000 and Austral Islands 'iripiti and tîfaifai in Hammond 1986a.

3. All of the Eastern Polynesian quilt and quilt-like textile traditions have connections to the indigenous barkcloth traditions that preceded the introduction of Western cloth into the islands. Barkcloth (called 'ahu or tapa in the Society Islands) was made extensively throughout Polynesia prior to European arrivals and is still created in Western Polynesia. Many scholars have remarked on the historical division, originating in the 19th century, between Western Polynesian societies which never abandoned the creation of barkcloth, even as they adopted Western cloth, and Eastern Polynesian societies which did. It should be noted that there is a revival of barkcloth, made in small quantities, in some of the islands of Eastern Polynesia today.

4. The more common use of the French term stems from France's influence on ideology about cultural heritage in French Polynesia, as well as the fact that islanders learn French in school and that French is widely used, especially in Tahiti where many cultural heritage events occur.

5. Performance analyses have been applied to other textile traditions such as the Hmong refugee pa ndau textiles and the US AIDS quilts.

6. Conventionally, quilts are defined as having a middle batting layer between an upper design surface and a lower backing layer, and quilting stitches secure all three layers together.

7. Although the cloth is imported, anything made from it is included in the general category of the traditional in the Heiva Rima' $\overline{1}$. Cloth (typically in the form of clothing) manufactured outside the islands was first introduced with the European voyages of discovery of the 18 th century.

8. The Society Islands (of which Tahiti is one island) and the other four archipelagos of French Polynesia are an overseas collectivity of France, and islanders born in French Polynesia are French citizens.

9. See Polynésie la 1ère, "16e salon du tifaifai de l'imagination et des couleurs", YouTube video, 1:19 (starting at 59 s), published 30 April 2014, accessed 29 April 2018, http://www.youtube.com/watch?v=O6vP8kOF2iQ.

10. Some men have also made tîfaifai; O'Reilly wrote of one in his 1959 article. In my trips to French Polynesia in the 2000s, I noted that many more men were involved in tifaifai creation than there were in the late 1970s, and they usually created designs that female relatives sewed. People accounted for this by saying that more people were now dependent on some income from making and selling tîfaifai.

11. Tcherkézoff (2004: 165) argues that Polynesians' wrapping of visitors in early contact encounters were actions that recognised the status of the other and, at the same time, were a way to envelop and incorporate whatever sacred powers the stranger possessed. 
12. While tîfaifai are still important wedding presents for couples in Tahiti, fewer couples are wrapped in tîfaifai these days according to many islanders.

13. Remnants from the clothing that islanders were encouraged to make and wear, following directives of Christian missionaries in the 19th century, may have been used for some early piecework tîfaifai. Striking colour contrasts in both piecework and appliqué styles could be achieved through the use of solid colours as opposed to used remnants of printed cloth. Tiffaifai made from new cloth would also have suited the ways in which tîfaifai substituted for the high-quality barkcloth made and used for special purposes. See de Chazeaux and Frémy's (2012: 33-39) work for a compilation of early accounts and descriptions of tîfaifai.

14. Only once has the piecework style of tïfaifai been designated as the type of tiffaifai necessary to qualify for participating in Te Api Nui O Te Tifaifai's annual Salon du Tīfaifai.

15. Tĩfaifai owned by households might also be employed for decoration for some public gatherings.

16. The first reenactment took place in 1954 following the reconstruction of Marae 'Ārahurahu.

17. In Dinéty's 2012 Patrimoines polynésiens, for example, there is no mention of tîfaifai, although pandanus weaving, sculpture, tattooing and pearl culture are discussed.

\section{REFERENCES}

Air Tahiti Magazine, 2016. Vol. 92 (Oct., Nov., Dec.): 73.

Akana, Elizabeth, 1981. Hawaiian Quilting: A Fine Art. Honolulu: The Hawaiian Mission Children's Society.

Appadurai, Arjun, 1996. Modernity at Large: Cultural Dimensions of Globalization. Minneapolis: University of Minnesota Press.

Appadurai, Arjun (ed.), 1986. The Social Life of Things: Commodities in Cultural Perspective. Cambridge: Cambridge University Press.

Arthur, Linda Boynton, 2010a. The Hawaiian Quilt: A Unique American Art Form. Waipahu, HI: Island Heritage Publishing. 2010b. Contemporary Hawaiian Quilting. Waipahu, HI: Island Heritage Publishing.

Barad, Karen, 2007. Meeting the Universe Halfway: Quantum Physics and the Entanglement of Matter and Meaning. Durham, NC: Duke University Press.

Bauman, Richard, 1989. American folklore studies and social transformation: A performance-centered perspective. Text and Performance Quarterly 9: 175-84.

Bell, Joshua A. and Haidy Geismar, 2009. Materialising Oceania: New ethnographies of things in Melanesia and Polynesia. The Australian Journal of Anthropology 20: $3-27$.

Brandon, Reiko Mochinaga and Loretta G.H. Woodard, 2003. Hawaiian Quilts: Tradition and Transition. Tokyo: Kokusai Art.

Brett, David, 1996. The Construction of Heritage. Cork: Cork University Press.

Clifford, James, 2001. Indigenous articulations. The Contemporary Pacific 13 (2): 468-90. 
Conquergood, Dwight, 1989. Poetics, play, process, and power: The performative turn in anthropology. Text and Performance Quarterly 9: 82-88.

1992. Fabricating culture: The textile art of Hmong refugee women. In E.C. Fine and J.H. Speer (eds), Performance, Culture and Identity. Westport, CN: Praeger, pp. 206-48.

Cumming, C.F., 1877. A Lady's Cruise in a French Man-of-War. 2 vols. London: Blackwood and Sons.

Cuzent, M.G., 1860. Îles de la Société. Rochefort: Imprimerie chez Thèze.

D'Alleva, Anne, 2005. Elite clothing and the social fabric of pre-colonial Tahiti. In S. Küchler G. Were and G. Jowitt (eds), The Art of Clothing: A Pacific Experience. London: UCL Press, pp. 47-60.

Dant, Tim, 1999. Material Culture in the Social World: Values, Activities, Lifestyles. Philadelphia: Open University Press.

de Chazeaux, Michèle and Marie-Noëlle Frémy, 2012. Le Tifaifai. Pirae, Tahiti: Editions Au Vent des Îles.

Dicks, Bella, 2003. Culture on Display: The Production of Contemporary Visitability. Maidenhead, UK: Open University Press.

Dinéty, Jean-Claude, 2012. Patrimoines polynésiens. Paris: L'Harmattan.

Durocher, Christian, 1997. 100 ans de patience pour le tifaifai. La Dépêche de Tahiti. April Wednesday 3: 26-27. Pape'ete, Tahiti.

Fienup-Riordan, Ann, 2000. Hunting Tradition in a Changing World: Yupu 'ik Lives in Alaska Today. New Brunswick, NJ: Rutgers University Press.

Fine, Elizabeth C. and Jean Haskell Speer (eds), 1992. Performance, Culture, and Identity. Westport, CN: Praeger.

Finney, Ben, 1979. Tahiti et Mama France. Conference paper for the 4th Annual Pacific Islands Studies Conference (held April 6-7), "The Emerging Pacific Island States." University of Hawai'i, Manoa.

Gell, Alfred, 1998. Art and Agency: An Anthropological Theory. Oxford: Clarendon Press.

Gloaguen, Ronan and Brenda Chin Foo, n.d. Tifaifai: The Tahitian Patchwork. Pape'ete, Tahiti: Ministère de l'économie et de l'artisanat, le Tomite Tahiti i te Rima Rau.

Grand, Simone, 2012. Te Tifaifai, Une narration gestuelle. Pape'ete, Tahiti: Editions Univers Polynésiens.

Hammond, Joyce D., 1986a. Tîfaifai and Quilts of Polynesia. Honolulu: University of Hawai'i Press.

1986b. Polynesian women and tīfaifai: Fabrications of identity. Journal of American Folklore 99 (393): 259-79.

2014. Tīfaifai in Tahiti: Embracing change. Uncoverings 35: 42-68.

2015. Tableau style tîfaifai of French Polynesia: An evolving narrative form. Textile: The Journal of Cloth and Culture 13 (2):176-209.

2017. Traditional Tahitian weddings for tourists: An entwinement of mimetic practices. In J.M. Mageo and E. Hermann (eds), Mimesis and Pacific Transcultural Encounters: Making Likenesses in Time, Trade, and Ritual Reconfigurations. New York: Berghahn Books, pp. 111-37. 
Herda, Phyllis S. 1999. Changing texture of textiles in Tonga. Journal of the Polynesian Society 108 (2): 149-67.

2000. Creating a new tradition: Quilting in Tonga. Uncoverings 21: 57-78.

2002. Cook Islands tivaevae: Migration and the display of culture in Aotearoa/

New Zealand. In A. Herle, N. Stanley, K. Stevenson and R.L. Welsch (eds),

Pacific Art: Persistence, Change and Meaning. Honolulu: University of Hawai' $\mathrm{i}$ Press, pp. 139-46.

2011. Tivaevae: Women's quilting in the Cook Islands. Uncoverings 32: 55-78. Hermann, Elfriede (ed.), 2011. Changing Contexts, Shifting Meanings:

Transformations of Cultural Traditions in Oceania. Honolulu: University of Hawai'i Press in association with the Honolulu Academy of Arts.

Hiro 'a, Journal d'informations culturelles, 2015. Tifaifai, trésor du patrimoine polynésien. Vol. 91 (April). Available at: http://www.hiroa.pf/2015/04/n91tifaifai-tresor-du-patrimoine-polynesien/

2018. Découvrir la culture polynésienne dès son arrivée au fenua. Vol. 127 (April). Available at: http://www.hiroa.pf/2018/04/n127-decouvrir-la-culturepolynesienne-des-son-arrivee-au-fenua/

Kaeppler, Adrienne L., 2008. The Pacific Arts of Polynesia and Micronesia. Oxford: Oxford University Press.

Kerlogue, Fiona, 2004. Performing Objects: Museums, Material Culture and Performance in Southeast Asia. London: The Horniman Museum and Gardens. Kooijman, Simon, 1988. Polynesian Barkcloth. Bucks, UK: Shire Publications.

Kopytoff, Igor, 1986. The cultural biography of things: commoditization as process.

In A. Appardurai (ed.), The Social Life of Things: Commodities in Cultural Perspective. Cambridge: Cambridge University Press, pp. 64-91.

Küchler, Susanne and Andrea Eimke, 2009. Tivaivai: The Social Fabric of the Cook Islands. London: The British Museum.

Küchler, Susanne, Graeme Were and Glenn Jowitt, 2005. Pacific Pattern. London: Thames \& Hudson.

Langevin, Christine, 1990. Tahitiennes de la tradition à l'intégration culturelle. Paris: L'Harmattan.

Latour, Bruno, 2005. Reassembling the Social: An Introduction to Actor-NetworkTheory. New York: Oxford University Press.

Martinson, Karen Jean, 2014. Relic, souvenir, or just hair? Exploring the complexities of actants and things as mementos in the merchandise of El Vez, the Mexican Elvis. In M. Schweitzer and J. Zerdy (eds), Performing Objects and Theatrical Things. New York: Palgrave Macmillan, pp. 173-84.

Miller, Daniel, 1987. Material Culture and Mass Consumption. Oxford: Blackwell. Miller, Daniel (ed.), 2005. Materiality. Durham, NC: Duke University Press.

O’Reilly, Patrick, 1959. Note sur les "ti fai fai" tahitiens. Journal de la Société des Océanistes 15: 166-77.

-1975. Tahiti au temps des cartes postales. Paris: Nouvelles Éditions Latines.

Poirrier, Philippe, 2003. Heritage and cultural policy in France under the Fifth Republic. International Journal of Cultural Policy 9 (2): 215-25.

Rongotea, Lynnsay, 2001. The Art of Tivaevae: Traditional Cook Islands Quilting. Honolulu: University of Hawai'i Press. 
Rose, Roger, 1971. The Material Culture of Ancient Tahiti. Unpublished PhD thesis, Harvard University.

Saura, Bruno, 2008. Tahiti Mā'ohi: Culture, identité, religion, et nationalisme en Polynésie française. Pirae, Tahiti: Au Vent des Îles.

Schouwenburg, Hans, 2015. "Back to the future?" History, material culture and new materialism. International Journal for History, Culture and Modernity 3 (1): 59-72.

Schweitzer, Marlis and Joanne Zerdy, 2014. Introduction. In M. Schweitzer and J. Zerdy (eds), Performing Objects and Theatrical Things. New York: Palgrave Macmillan, pp. 1-17.

Serrao, Poakalani, John Serrao, Raelene Correia and Cissy Serrao. 2007. The Hawaiian Quilt: The Tradition Continues. Honolulu: Mutual Publishing.

Smith, Laurajane. 2006. Uses of Heritage. New York: Routledge. 2011. The "doing" of heritage: Heritage as performance. In A. Jackson and J. Kidd (eds), Performing Heritage: Research, Practice and Innovation in Museum Theatre and Live Interpretation. Manchester: Manchester University Press, pp. 69-81.

Stevenson, Karen, 1990. "Heiva": Continuity and change of a Tahitian celebration. The Contemporary Pacific 2 (2): 255-78.

2002. The island in the urban: Contemporary Pacific art in New Zealand. In A. Herle, N. Stanley, K. Stevenson and R.L.Welsch (eds), Pacific Art: Persistence, Change and Meaning. Honolulu: University of Hawai'i Press, pp. 404-14.

Storey, John, 2017. Culture: The "popular" and the "material". In A. Malinowska and K. Lebek (eds), Materiality and Popular Culture. New York: Routledge, pp. 13-24.

Tcherkézoff, Serge, 2003. On cloth, gifts and nudity: Regarding some European misunderstandings during early encounters in Polynesia. In C. Colchester (ed), Clothing the Pacific. New York: Berg, pp. 51-75.

2004. "First Contacts" in Polynesia: The Samoan Case (1722-1848): Western Misunderstandings about Sexuality and Divinity. Canberra: ANU Press.

Thomas, Nicholas, 1991. Entangled Objects: Exchange, Material Culture, and Colonialism in the Pacific. Cambridge: Harvard University Press.

Turner, Victor, 1986. The Anthropology of Performance. New York: PAJ Publications. van Binsbergen, Wim, 2005. Introduction. In W.M.J. van Binsbergen and P.L. Geshiere (eds), Commodification: Things, Agency, and Identities (The Social Life of Things Revisited). Münster: Lit, pp. 9-51.

Varutti, Marzia, 2015. Crafting heritage: Artisans and the making of indigenous heritage in contemporary Taiwan. International Journal of Heritage Studies 21 (10): 1036-49.

Warren, Karen J., 2000. Ecofeminist Philosophy: A Western Perspective on What It Is and Why It Matters. New York: Rowman and Littlefield Publishers.

Wettstein, Marion, 2016. How ethnic identity becomes real: The enactment of identity roles and the material manifestation of shifting identities among the Nagas. Asian Ethnicity 17 (3): 384-99. 


\begin{abstract}
Tîfaifai, the visually striking piecework and appliqué textiles (sometimes referred to as quilts) that islanders of Tahiti and other locations in French Polynesia have created for over 150 years, are increasingly part of a public cultural heritage discourse. Focusing on appliqué tîfaifai, the most popular form in the Society Islands for many decades, I examine the contemporary role of tiffaifai in conveying messages of cultural heritage in public places and events. My analysis draws from new materialism theory, performance studies and visual display concepts. As actants, tïfaifai have agency and are co-constitutive with people who may interact with them in various ways. A variety of performative contexts in which tïfaifai are displayed and used reveal the breadth of messages that are conveyed which reinforce and expand aspects of Mā'ohi cultural heritage and identity. A biographical approach to tīfaifai as a form of material culture is included to illustrate the ways in which the actions of people, government policies, economic circumstances and other impactful phenomena have led to the contemporary role of tïfaifai as both objects and symbols of cultural heritage. This study aids in understanding how cultural heritage may be understood and performed by local communities through the medium of a continuous, evolving textile tradition.
\end{abstract}

Keywords: tīfaifai, Tahiti, cultural heritage, patrimoine, identity, new materialism theory, performance, textile traditions, quilts

\title{
CITATION AND AUTHOR CONTACT DETAILS
}

Hammond, ${ }^{1}$ Joyce D., 2018. Performing cultural heritage with tîfaifai, Tahitian "quilts". Journal of the Polynesian Society 127 (2): 207-248. DOI: http://dx.doi. org/10.15286/jps.127.2.207-248

${ }^{1}$ Correspondence: Department of Anthropology, Western Washington University, Bellingham, Washington 98225, USA. Email: joyce.hammond@wwu.edu 